
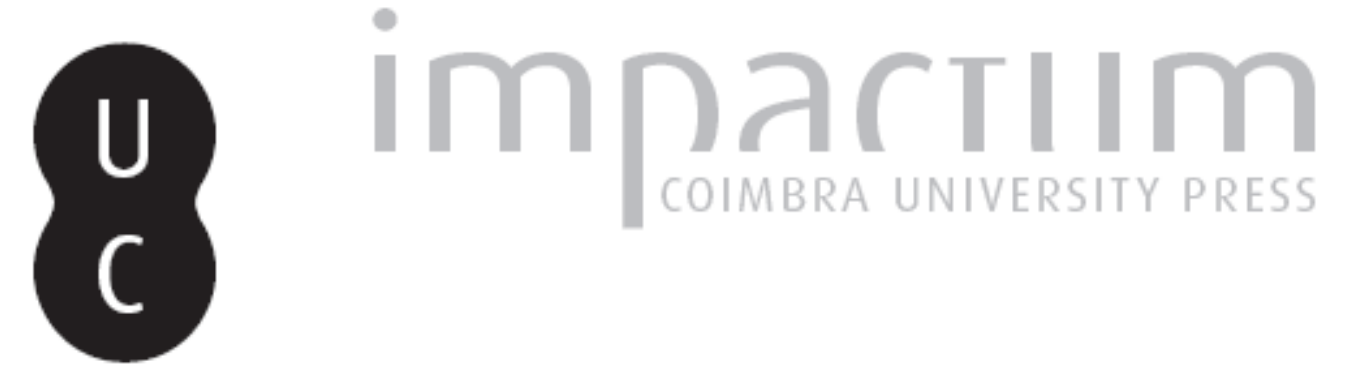

\title{
Luanda e os seus dois arcos complexos de vulnerabilidade e risco: 0 das restingas e ilhas baixas e o das escarpas abarrocadas
}

Autor(es): $\quad$ Amaral, llídio do

Publicado por: Associação Portuguesa de Riscos, Prevenção e Segurança

URL persistente:

URI:http://hdl.handle.net/10316.2/40088

DOI:

DOI:https://doi.org/10.14195/1647-7723_9_6

Accessed : $\quad$ 26-Apr-2023 11:44:03

A navegação consulta e descarregamento dos títulos inseridos nas Bibliotecas Digitais UC Digitalis, UC Pombalina e UC Impactum, pressupõem a aceitação plena e sem reservas dos Termos e Condições de Uso destas Bibliotecas Digitais, disponíveis em https://digitalis.uc.pt/pt-pt/termos.

Conforme exposto nos referidos Termos e Condições de Uso, o descarregamento de títulos de acesso restrito requer uma licença válida de autorização devendo o utilizador aceder ao(s) documento(s) a partir de um endereço de IP da instituição detentora da supramencionada licença.

Ao utilizador é apenas permitido o descarregamento para uso pessoal, pelo que o emprego do(s) título(s) descarregado(s) para outro fim, designadamente comercial, carece de autorização do respetivo autor ou editor da obra.

Na medida em que todas as obras da UC Digitalis se encontram protegidas pelo Código do Direito de Autor e Direitos Conexos e demais legislação aplicável, toda a cópia, parcial ou total, deste documento, nos casos em que é legalmente admitida, deverá conter ou fazer-se acompanhar por este aviso.

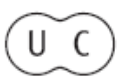




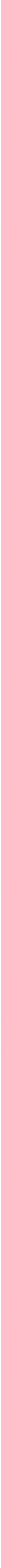




\section{Luanda e os seus dois arcos complexos de vulnerabilidade e risco: o das restingas e ilhas baixas e o das escarpas abarrocadas}

\author{
Ilidio do Amaral*
}

\author{
"Nature to be commanded must be obeyed" \\ (Francis Bacon, Novum Organum, 1620). \\ "A vulnerabilidade é intrínseca à noção de risco" \\ (Fernando Rebelo, Riscos naturais e Acção antrópica, 2001).
}

\section{Resumo:}

Luanda e os seus dois arcos complexos de vulnerabilidade e risco: das restingas longas e ilhas baixas de areias siliciosas, e das escarpas moldadas em camadas sedimentares brandas com algumas intercalações de rochas mais resistentes, densamente abarrocadas. Clima caracterizado pela alternância de um período curto de chuvas fortes nos meses mais quentes, os primeiros do ano, e de um longo período seco, com meses menos quentes (cacimbo); vegetação do tipo savana acusando ambiência de semi-aridez, bem representada sobre as areias vermelhas que cobrem o planalto. Modificações naturais e perturbações resultantes de intervenções humanas. A necessidade de medidas correctas para o acompanhamento e minoração dos efeitos negativos da erosão marinha e da erosão terrestre.

Palavras chave:

Luanda (Angola), Geomorfologia, Restingas e ilhas, Escarpas, Barrocas, Vulnerabilidade, Riscos naturais, Acções humanas, Gestão de riscos.

\section{Résumé:}

Luanda et ses deux ares complexes de vulnérabilité et risque: celui des restingas (flèches littorales) et des petites îles de sables qui protégent la baie d'eaux calmes de la ville contre les houles de l'Océan et celui des falaises modelées sur des couches sédimentaires peu résistantes et avec trop de barrocas ou ravins. Climat caracterisé par l' alternance de deux périodes: pendat les premiers mois de l'an, les plus chauds, tombent des pluies vigoreuses; la période suivante est longue et sèche, avec des mois moins chauds (le cacimbo); la végétation du type savanne accusant I'ambiance semi-aride, est bien représentée sur les sables rouges qui couvrent le plateau. Modifications naturelles et perturbations résultantes des interventions humaines. De la nécessité de mesures correctes de surveillance et d'amoindrissement des effets négatifs de l'érosion maritime et de l'érosion terrestre.

Mots clés:

Luanda (Ángola), Géomorphologie, Restingas (flèches littorales) et îles, Escarpements, Ravines, Vulnerabilité, Risques naturels, Actions humaines, Gestion de risques.

\section{Abstract:}

Luanda and its two complex arches of vulnerability and hazard: that of the sandy and low restingas (spits) and small islands that protect the bay of still waters of the town against the oceanic waves, and that of the escarpments in bedded sedimentary rocks densely gullyed. Tropical littoral savannna climate with alternation of a short period of heavy rainfalls during the first months of the year, the hottest, and a long and dry period, with lower temperatures (the cacimbo); the vegetation cover is a grassland with interspersed trees and shrubs, well represented on the plateau coated with red sands. The natural changes and those resulting from men's actions. The necessity of appropriated policies to survey the negative effects of the erosional processes.

Key Words:

Luanda (Angola), Geomorphology, Restingas (spits) and islands, Escarpments, Gullies, Vulnerability, Natural hazards, Men's actions, Risk managemenst, Land use planning.

\section{Introdução}

Começo por agradecer à Comissão Organizadora do VIII Encontro sobre Riscos Naturais: Vulnerabilidade e Crise o amável convite que me dirigiu para participar com uma comunicação e, mais do que isso, o facto de ter inserido no folheto de apresentação do evento, quase como lema, um excerto do meu livro Luanda. Estudo de geografia urbana, 1968, acerca dos efeitos catastróficos das enxurradas resultantes de chuvas tempestuosas que se abatem sobre a cidade e a sua região nos primeiros meses do ano, quando as temperaturas do ar são também mais elevadas.

\footnotetext{
* Geógrafo, Professor Catedrático Jubilado da Universidade de Lisboa. Director do Centro de Geografia do Instituto de Investigação Científica Tropical (ICT).
}

Tendo-me sido facultada a liberdade de escolha do tema, perante o relevo dado à citação achei por bem voltar aos problemas da urbe onde nasci e vivi uma boa parte da infância e juventude, da qual viria muitos anos depois a ocupar-me, como geógrafo, continuando a fazê-lo ao preparar, neste momento, uma edição actualizada e mais desenvolvida daquele livro. A partir dos tópicos apresentados no curto espaço de tempo da comunicação oral desenvolvi este tex to e procurei fazê-lo com linguagem simples.

Luanda está no centro da área de afloramentos de camadas sedimentares da Bacia do Cuanza, cerca de $4000 \mathrm{~m}$ de espessura total, depositadas desde o Apciano-Albiano Inferiore assentes, as mais antigas, em superfície irregular de rochas cristalinas do Maciço Antigo. Naquelas formações, com estruturas variadas mas predominando, nas mais recentes, os dispositivos 
monoclinais, por vezes quase horizontais, os processos erosivos modelaram escarpas intensamente abarrocadas, sobretudo nos do Miocénico superior e inferior constituídos pela alternância de rochas calcárias, greso-calcárias, areníticas, margosas, argilosas, de areias brancas ferruginosas com leitos de burgaus ou burgalhos (o correspondente de cascalhos).

Sobre tudo isso estão as areias vermelhas ou amarelo-acastanhadas, Plistocénicas, ditas dos "muceques", com espessuras varáveis, até algumas dezena de metros, cobrindo peneplanície do final do Terciário. Revestem o planalto de Luanda, com 40 a $80 \mathrm{~m}$ altitude na Cidade e áreas envolventes. Análises das areias vermelhas, de amostras colhidas em vários locais, permitiram concluir que são de grãos médios e finos, muito bem calibradas e de origem marinha, com retoques eólicos, que "a sua composição granulométrica écaracterizada por percentagens de partículas de areias superiores a $80 \%$, partículas de limo da ordem de $1 \%$ a $5 \%$ e partículas de argila com percentagens da ordem dos $8 \%$ a $15 \% "$. O leitos de burgaus que se encontram sob as areias mostram que o cascalho de quartzo também teve rolamento marinho (G. Soares de Carvalho, 1964, p. 698).

Do outro lado, no mar, fica a grinalda de cordões de areias siliciosas e claras de uma restinga com cerca de $34 \mathrm{~km}$ de comprimento, desde a Ponta das Palmeirinhas, onde está ligada ao continente, até à Ponta do Mussulo, com as suas ilhas e ilhotas na laguna interior. Segue-se a Barra da Corimba, abertura de mais ou menos $6 \mathrm{~km}$, e depois a flecha estreita da Ilha de Luanda, que protege a baía da cidade, com uma extensão de perto de $12 \mathrm{~km}$ até à Ponta da Ilha (fig. 1). Por esta grinalda dou início à apresentação dos problemas.

\section{Luanda e a sua grinalda de restingas e ilhas}

Em meados do século XVI, à chegada dos portugueses a essas paragens, já existia a barra da Corimba e por ela entraram os primeiros barcos, para fundearem em frente do local que ficaria conhecido como Praia do Bispo. Um pouco mais tarde as preferências foram dadas aos ancoradouros e às praias voltadas para norte, mais abrigadas dos ventos dominantes de oeste e sudoeste pelo morro que serviu de núcleo primordial da povoação.e vila de Luanda, onde viria a ser construída a fortaleza de São Miguel.

$\mathrm{Na}$ opinião dos padres jesuítas que em 1575 acompanharam Paulo Dias de Novais, o primeiro governador e conquistador do "reino de Angola", a ilha formava uma barreira de protecção a um dos melhores portos do litoral africano conhecido naquele século. Outros observadores perspicazes, como o comerciante e viajante Duarte Lopes, de famílias judaicas de Benavente, chegado a Angola em 1578, e o padre jesuíta Garcia Simões, companheiro de Paulo Dias de Novais e autor de numerosas cartas e relatórios, registariam que a restinga era "feita de areia e vaza do mar e do rio Cuanza", a partir do encontro dos "seus cursos $/ . . . /$, caindo ao fundo a matéria" (D. Lopes e F. Pigafetta, in I. do Amaral, 2000, pp. 77-81); mantinha-se assim a faixa de "terra mui baixa /.../ que apenas" se elevava "do mar" (Garcia Simões, in Idem, idem).

Segundo o padre, a "ilha" media "cinco léguas em comprido, e de largo um tiro de espingarda", mas em certos lugares era "mais estreita". Noutros termos se referiram Duarte Lopes e F. Pigafetta, dando-lhe 20 milhas de comprimento e de largura, "quando muito, uma milha e em alguns lugares um tiro de arco somente" (D. Lopes e F. Pigafetta, in Idem). O autor anónimo de uma relação de 1607 , reproduzindo informações anteriores, avaliava as dimensões em "cinco léguas de comprido e de largo menos de meia légua, e a partes um tiro de arcabuz" (In Idem).

Ainda em conformidade com as mesmas fontes, em alguns pontos a ilha distava do litoral continental fronteiro cerca de "meia légua" (Padre Garcia Simões), mas noutros ela estava "vizinhíssima à terra", o que permitia aos ilhéus atravessarem a nado o estreito canal. Na baixamar emergiam "algumas ilhetas", todas elas com árvores grandes, aos troncos das quais" se apegavam "boníssimas ostras" (D. Lopes e F. Pigafetta, in Idem), referindo-se, certamente, ao sector de laguna abrigado pela restinga de PalmeirinhasMussulo. Nesses cordões arenosos não havia águas correntes, mas podia ser obtida alguma "água doce, muito boa, cavando", segundo uns, "uma braça ou menos" nas areias ou, segundo outros, "dois ou três palmos de fundo". Porém, a boa qualidade durava apenas "poucos dias" pois o precioso líquido tornavase salobro.

As medidas acima indicadas representam cerca de 20 a $30-35 \mathrm{~km}$ de comprimento e de 2 a $3 \mathrm{~km}$ de largura. Fica a dúvida se esses autores antigos consideravam como "ilha" somente a flecha arenosa defronte da cidade, que tem, actualmente, perto de $12 \mathrm{~km}$ de comprimento, ou se referiam a totalidade com a restinga de Palmeirinhas-Mussulo, a qual, nos dias de hoje, só ela mede cerca de $32 \mathrm{~km}$.

A origem dos cordões arenosos mergulha, provavelmente, em finais do Quaternário, no período da regressão flandriana, mas as configurações das restingas e das ilhas têm mudado ao longo dos tempos, como demonstram fenómenos visíveis na actualidade.

A restinga de Palmeirinhas-Mussulo é uma das poucas grandes formas de ponta livre e arredondada em báculo, com barbela, na costa atlântica de África. Ela começa alguns quilómetros a norte da foz do rio Cuanza (fig. 1), no prolongamento de uma série de 


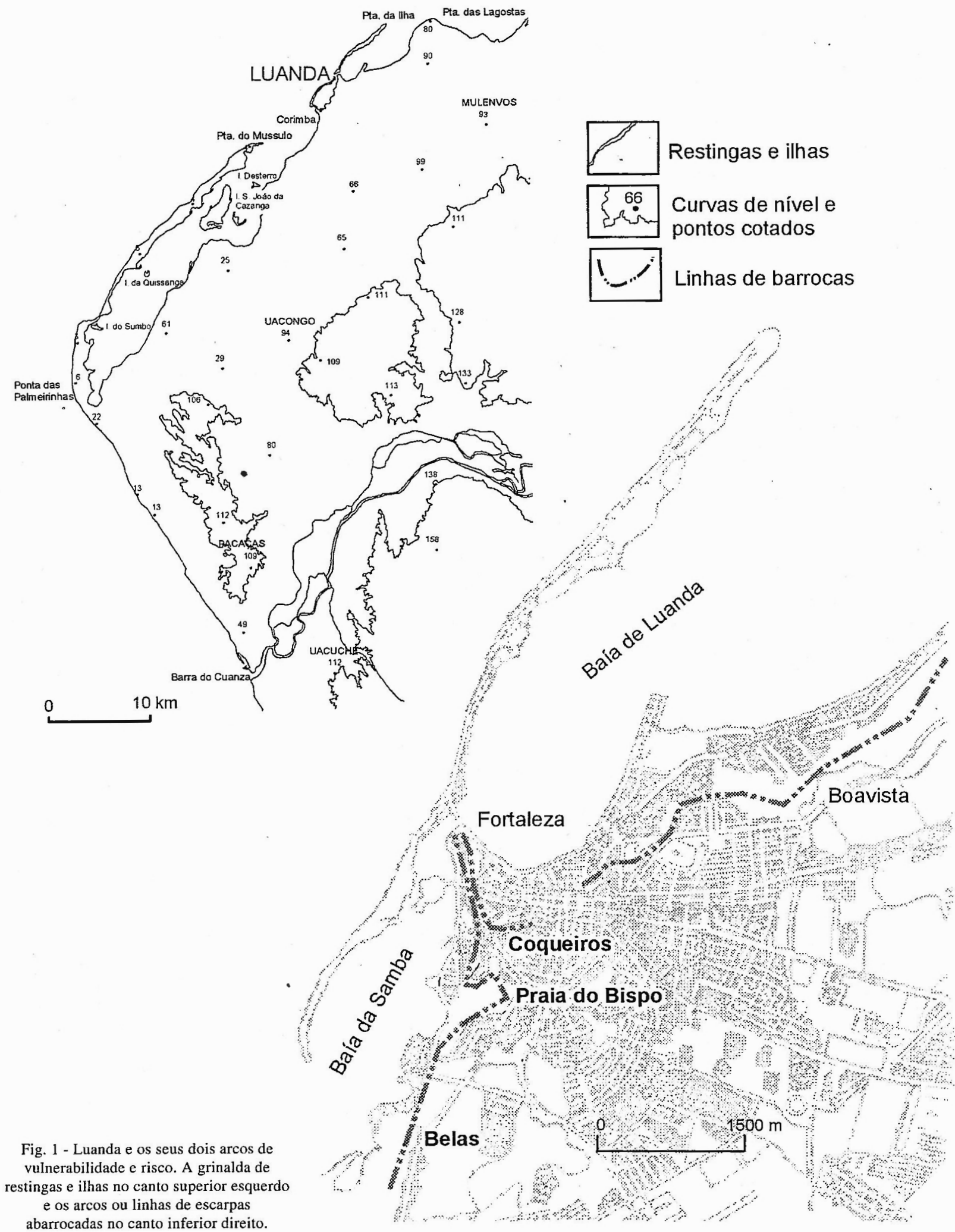


praias de cerca $18 \mathrm{~km}$ de comprimento orientada SSE-NNO, constituída por cordões de areias cujas altitudes médias rondam a meia dúzia de metros. Em vários locais existem dunas de alturas fracas (12 a 20 $\mathrm{m})$. As praias estão na base de uma frente de arribas mortas cujos cimos marcam os limites de um planalto Pliocénico com altitudes de 50 a $90 \mathrm{~m}$, coberto por areias vermelhas de grande erodibilidade assentes, em muitos sectores, sobre extensas lentes de argila ou silte limoso. Estas condições favorecem, em período de chuvas, a formação de lagoas ou cacimbas de diversos tamanhos, a maior parte delas de carácter sazonal. As escarpas apresentam-se fortemente dissecadas por barrocas ou ravinas instáveis cujas cabeceiras regridem em cabeleiras complexas sobre o planalto.

A restinga destaca-se do continente onde a costa toma uma direcção NNE, mais ou menos na Ponta das Palmeirinhas (8-9 $\mathrm{m}$ de altitude), abrindo-se assim oespaço da laguna longa $(30 \mathrm{~km})$ e relativamente estreita $(5-6 \mathrm{~km})$ com ilhas e ilhotas: do sul para norte, as mais importantes das primeiras são as do Sumbo (1-2 m de altitude), da Quissanga ( $3 \mathrm{~m})$, de São João da Cazanga (3-4 m), a maior de todas, dos Pássaros (2 m) e do Desterro ( $2 \mathrm{~m})$. A laguna tem outros elementos interessantes, como canais, bancos pouco profundos, áreas com plantas halófilas e mangais, especialmente a sudoeste.

A manga de areias começa por uma faixa de um pouco mais de $1 \mathrm{~km}$ de largura e altitudes que rondam os 4 a $5 \mathrm{~m}$, estirada, primeiramente, de sul para norte. Contudo, a cerca de $9 \mathrm{~km}$ do seu enraizamento continental, tem uma curvatura brusca, em cotovelo, para leste e um forte estreitamento, a partir do qual progride, ligeiramente arqueada, para NE, mantendo um certo paralelismo com a costa (fig. 1). A mudança de rumo e o estreitamento parecem corresponder, tendo em conta fenómenos idênticos e recentes observáveis na ilha de Luanda, a uma ruptura antiga dos cordões arenosos e sutura posterior. Na verdade, a montante do cotovelo existe na laguna um canal bastante profundo que termina, bruscamente, contra a restinga, o que só pode ser explicado pela existência de uma antiga passagem, muito anterior à chegada dos portugueses a essa área, pois não há qualquer referência a ela nos documentos minuciosos escritos pelos observadores mais antigos.

Até à Ponta do Mussulo as fotografias aéreas mostram numerosos cordões sucessivos, muitas vezes cortados pelas praias oceânicas actuais ou por cordões mais recentes segundo um ângulo mais ou menos forte, que revelam "um desenvol vimento com migração do fulcro, normal neste tipo de construção" (A. Guilcher et alia, 1974, p. 205). No interior da laguna, quer nas margens da restinga, quer nas do continente, quer mesmoligadas às ilhas, desenvolvem-se pequenas flechas de areias, semelhantes a pequenas restingas, sob a influência das vagas locais de curta ondulação levantadas pelos ventos de sudoeste.

A Ilha de Luanda deixou de ser tal forma natural em finais dos anos 20 do século passado, quando foi construída a primeira ponte, de madeira, ligando-a, definitivamente, ao continente no sopé da Fortaleza de São Miguel (figs. 1, 14 e 15). Muito mais tarde essa ponte foi substituída por outra, uma barreira de cimento, sem aberturas, o que teve impactos importantes no sistema milenar de circulação das águas, na própria Ilha e no sector da baía para sul, da Praia do Bispo e das Sambas, conhecido por Baía da Samba.

A Ilha tem uma largura média de $200 \mathrm{~m}$, portanto muito inferior à da restinga de Palmeirinhas-Mussulo, e poderá ter sido, em tempos bem antigos, uma restinga enraizada no continente por alturas das praias de Corimba-Samba tendendo sempre a alongar-se para nordeste, como a anterior. Tudo indica que, actualmente, essa provável antiga restinga está em processo de degradação: demasiado estreita, o seu alongamento terá sido feito, apenas, à custa da sua parte interna, de sudoeste.

O desenvolvimento da restinga de Palmeirinhas-Mussulo, abrigando longamente o litoral continental, tem-na privado da alimentação de areias que poderiam resultar do ataque oblíquo da ondulação oceânica. Segundo os autores anteriormente citados (A. Guilcher et alia), contradizendo uma hipótese de ter havido uma posição mais setentrional da foz do rio Cuanza e a sua migração posterior para a actual, o exame minucioso das fotografias aéreas da ilha de São João da Cazanga revela que, apesar da sua posição muito abrigada na laguna da grande restinga, ela é percorrida por uma série de longos cordões arenosos paralelos e alongados sudoeste-nordeste, o que mostra a possibilidade de poder ter sido essa ilha a parte mais antiga e meridional de uma restinga de Luanda.

Esta poderá ter sido formada numa época em que a de Palmeirinhas-Mussulo era muito menos longa e em que a ilha de São João da Cazanga era batida pelas ondas oceânicas. Posteriormente, o crescimento daquela restinga, ultrapassando a ilha, poderá ter tido como resultado edificar um quebra-mar para a parte inicial da de Luanda, prejudicando a sua alimentação e permanência. No entanto, a parte externa terá continuado a desenvolver-se, mas apenas à custa da deriva de areias para NE. Daí a decrepitude e a fragmentação que ameaçam a Ilha de Luanda.

As calemas, isto é, as rebentações violentas das ondas oceânicas na linha de praias da contra-costa em períodos tempestuosos, intensificadas quer na forma encapelada, quer na de derrame ou efervescência, quer ainda na enrolada ou em vagalhão e a sua penetração pela Barra da Corimba, passaram a ter efeitos reforçados dos quais resultaram, em anos de 
maior intensidade dos fenómenos oceânicos, cortes da flecha arenosa da Ilha. Recordo apenas os exemplos das calemas de 1944, na área da Cabeleira, a sul do paredão da ponte de cimento, que destruiu várias casas, uma delas possuída pela minha família, e de 1955, que cortaram a Ilha em sector fronteiro ao centro da cidade, a norte daquela mesma ponte.

Doeu-me muito a destruição da casa da Ilha onde passei excelentes momentos de infância e juventude, recordações que jamais foram varridas da minha memória, de tempos de grande liberdade ao ar livre, ora a correr descalço pelos areais, ora nas águas encapeladas do Oceano a "furar" a nado as cristas das ondas alterosas (segundo a tradição, era preciso "furar" séries de sete, separadas por cavas de grande comprimento), numa altura em que ainda não havia pranchas, nem surf, ora a chimbicar uma canoa feita do tronco de certas árvore, nas águas muito mais calmas da baía e a praticar o lançamento da rede redonda. O segundo termo em itálico, da gente da Ilha, aplicava-se ao acto de alguém, colocado de pé na popa, fazer deslizar a canoa com a ajuda de uma vara comprida, capaz de chegar ao fundo das águas, manejando-a ora de um lado, ora do outro da embarcação. Quantas vezes, ainda mal nascera o sol, já eu e os meus irmãos estávamos na praia a aguardạr o regresso dos pescadores, pelo prazer de os ajudarmos a puxarem as redes e as canoas para terra, e a recolherem o peixe, e de recebermos, em retribuição, petingas e outros peixes miúdos para fritar!

$\mathrm{O}$ aumento da densidade de construções sobre as areias (habitações e barracas, restaurantes e hotéis, clubes desportivos e nocturnos, arruamentos e outras infra-estruturas), a falta de medidas adequadas de florestação e de conservação dos núcleos de vegetação contribuíram também para reforçar os efeitos erosivos das águas do mar, com arrastamento cada vez maior das areias. Como formas de protecção houve que proceder ao enrocamento de algumas praias oceânicas e à construção de esporões de blocos de betão e de pedras normais à direcção das mesmas (figs. 2 e 14). Do outro lado da Ilha, nas águas calmas da baía aumentam sem parar as cargas de sedimentos transportados pelas enxurradas, quer em toalhas de frentes amplas, quer canalizadas pelas barrocas e pelas ruas, quer fornecidas pelos esgotos e obras da cidade.

Ora a Ilha foi sempre um sistema vulnerável, que sobreviveu em certo equilíbrio sustentável enquanto a habitaram, em nítida maioria, pescadores indígenas com os seus modos de vida tradicionais, de fraco impacto na natureza insular. O aumento desregrado de ocupação humana e das suas obras tornou-a ainda mais vulnerável aos processos erosivos, tendo $\mathrm{em}$ conta até que era notório que estava privada de receber areias de sul. Referir-me-ei, mais adiante, outro tipo de erro cometido muito recentemente, o do assoreamento da parte da baía entre a Praia do Bispo, no continente, e a Chicala, na Ilha, formando-se a Chicala II.

\section{Escarpas abarrocadas no interior da área urbanizada}

Luanda, fundada em 1576, desde cedo, ainda não terminara o século XVI, foi crescendo em dois planos escalonados: o da "Cidade Alta", num sector de planalto, bem arejado pelos ventos e brisas marítimas, ocupada pelos serviços públicos e gentes do governo e da administração, quer civil, quer militar, quer religiosa, e o da "Cidade Baixa", na praia, menos "salutífera", sede do comércio e da navegação, que até tarde tiveram como principais objectivos os escravos e o seu tráfico transatlântico, e habitada por gente menos abastada ou de menor estatuto social. Entre as duas partes da aglomeração se interpunham as escarpas, antigas arribas que em tempos recuados passaram a evolver como vertentes, desde o momento em que os processos da erosão marinha deixaram de actuar directamente sobre as suas bases e se construíram as praias que as orlam. Chegam a ter $50 \mathrm{~m}$ de altura e mais, estão densamente abarrocadas, e continuadas a norte por arribas ainda vivas que se prolongam um pouco para lá da Ponta das Lagostas (fig. 9).

De um modo geral, as principais áreas de barrocas, barrancos ou ravinas dendríticas que dissecam as escarpas da cidade podem ser agrupadas, teoricamente, em três conjuntos: um do lado norte, da Boavista ao Cemitério do Alto das Cruzes e mais adiante o Largo do Kinaxixe, com abruptos imponentes, outro, mais voltado para noroeste, dos tradicionais bairros de Ingombotas e Coqueiros ao morro da Fortaleza de S. Miguel, e o terceiro, o mais extenso, francamente voltado para oeste, desde este morro, pela Praia do Bispo, até às Sambas, com prolongamento de outros dispostos em áreas que se alongam por Belas e mais para sul, na direcção do Cuanza (fig. 1).

Para além destes arcos litorais, que seleccionei para este texto, há muitas outras barrocas e quase se pode dizer que existem por toda a parte, quer nas áreas urbanizadas, quer nos bairros periféricos, os muceques, no sentido de bairros de lata com todas as gradações de miséria. A população de Luanda, na sua totalidade, foi-se dilatando, desmesuradamente, nos anos depois da Independência, não apenas em resultado de crescimento natural mas, sobretudo, da invasão de multidões fugidas das áreas rurais e de outros centros urbanos de regiões assoladas pela guerra. Sem haver estatísticas credíveis, há quem estime a população da cidade em 2,5 milhões, outros referem 3 milhões, em qualquer dos casos cerca da quarta parte do que se estima como população do 


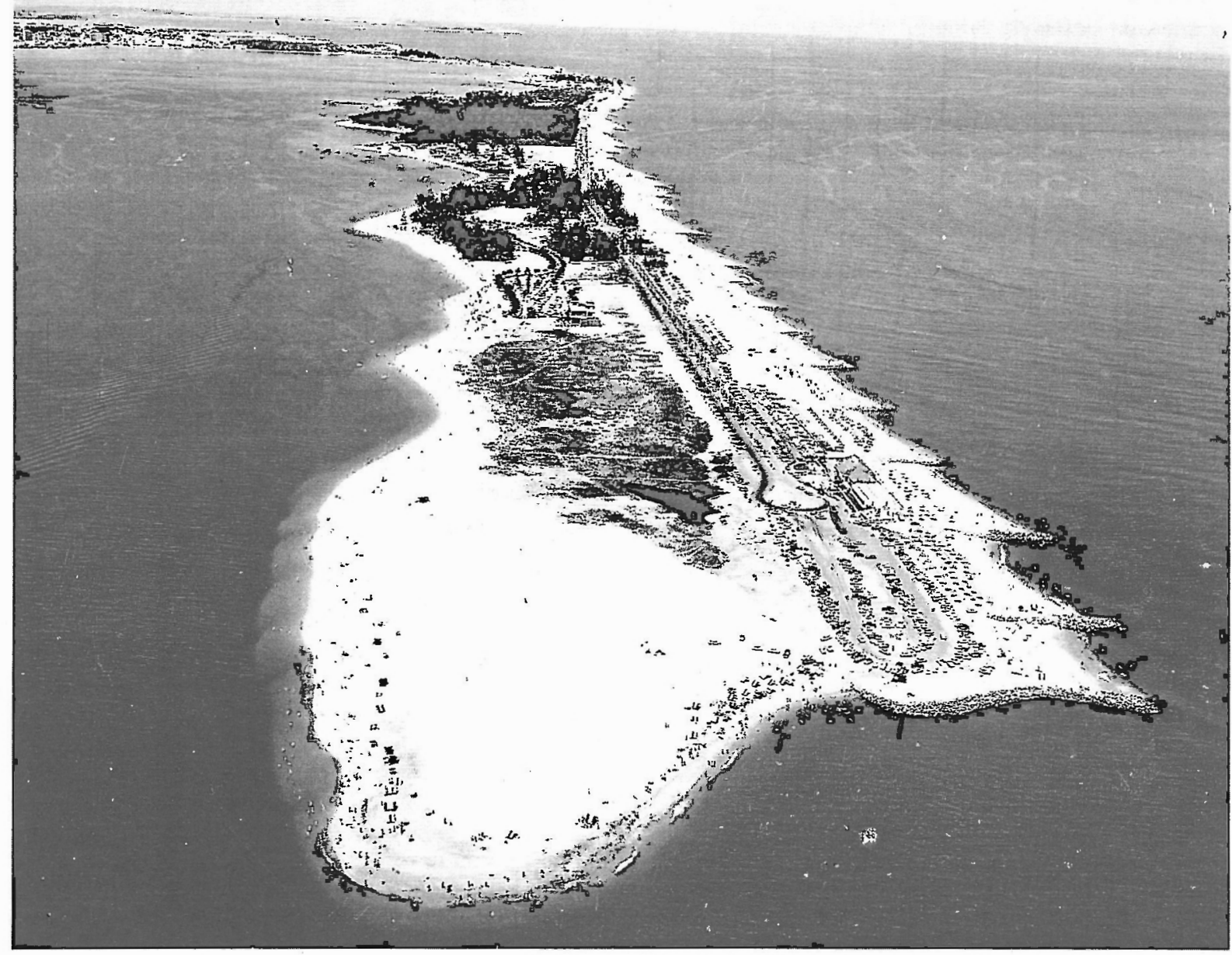

Fig. 2 - A Ilha de Luanda, desde a Ponta, com os seus esporões de blocos rochoșos e de betão no lado oceânico.

país, e também aparecem os que, sem bases conhecidas, citam números acima daqueles. Hoje, o que se vê no terreno é que os muceques, que rodeiam a cidade por todos os lados, ultrapassam em muitas vezes a área urbanizada. Um dos maiores e mais recentes, o de Rocha Pinto, avança, sem dificuldades, no planalto a sul do aeroporto, como mancha de óleo sobre superfície lisa. Mas os muceques também se esparramam alcandorados em barrocas alcantiladas.

Há mais de trinta anos, no meu livro de 1968, quando a população da cidade rondava os escassos * 250.000 habitantes, ao ocupar-me dos muceques já escrevia que, "no conjunto dos problemas" urbanos, ele era, "sem dúvida, o de maior gravidade e o de resolução global, pode dizer-se, impossível" (I. do Amaral, 1968, p. 115). Passados trinta anos a situação piorou, exponencialmente, e nos dias de hoje qualquer tentativa de resolução global dos problemas urbanos já nasce votada ao insucesso, tantas são as situações complicadas, a par das de vulnerabilidade e riscos nessa cidade de elevado grau de macrocefalia.

O morro da Fortaleza (figs. 3 e 14), com as suas bancadas de calcários duros (fauna burdigaliana), intercaladas num conjunto de areias amarelas com fósseis de lamelibrânquios, areias finas e brancas quase puras ( 90 p. 100 de grãos de quartzo), conglomerados com cimento calcário silicificado, constitui uma espécie de molhe resistente à erosão, ponto de divergência ou mudança das orientações predominantes dos arcos de barrocas (fig. 1). É possível que uma ou mais falhas profundas tenham sido responsáveis pelos arranjos estruturais do morro e das suas áreas circundantes.

A planta da cidade ainda hoje é dominada pelos elementos topográficos anteriormente referidos. $\mathrm{Na}$ sua parte da Baixa é relevante a conjugação dos obstáculos dos arcos das barrocas com as forças atractivas das funções portuárias localizadas numa 


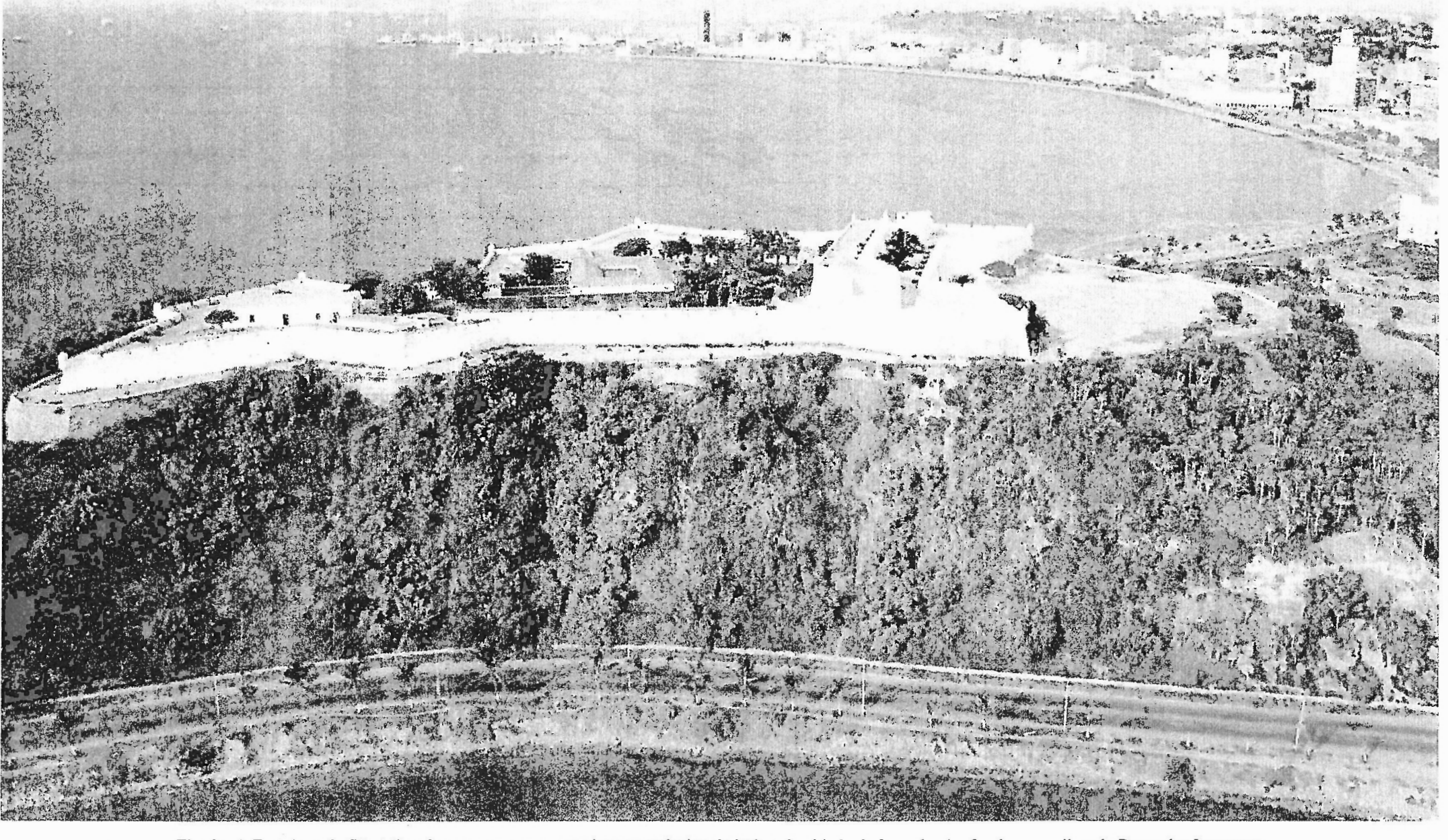

Fig. 3 - A Fortaleza de São Miguel, o seu morro e uma vista panorâmica da baía e da cidade de Luanda. Ao fundo, as arribas da Ponta das Lagostas. 


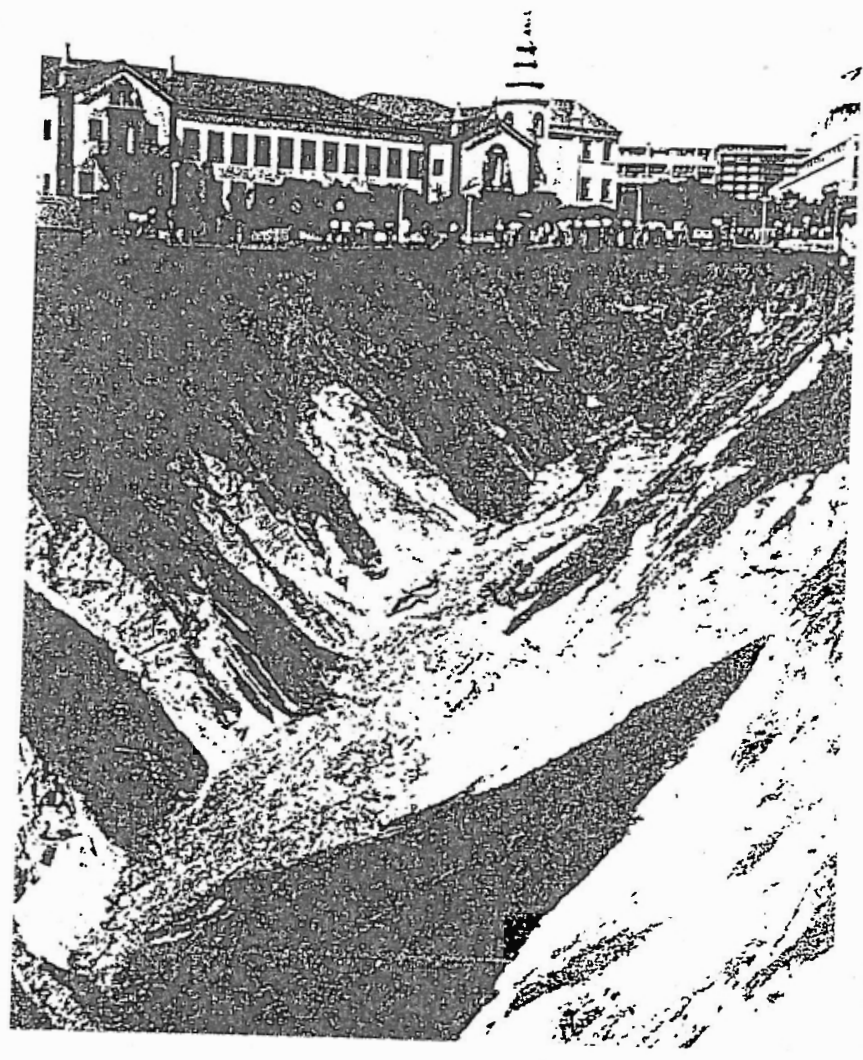

Fig. 4 - Abertura de uma barroca ou ravina profunda da Rua e N..$^{2} r^{2}$ da Muxima, por efeito das águas torrenciais de chuvas intensas de Abril de 1963.

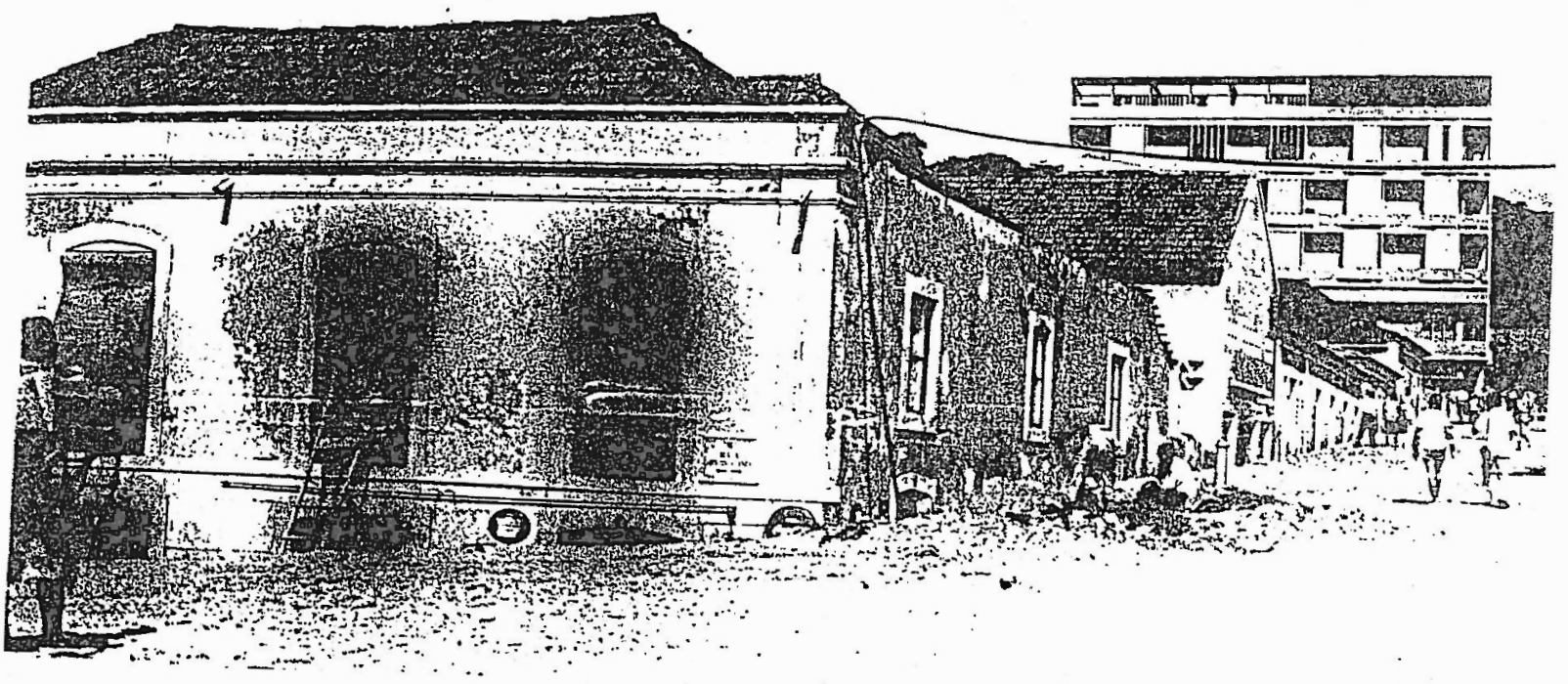

Fig. 5 - Depósitos de areias e lamas num local da Cidade Baixa, arrastadas pelas torrentes formadas pelas chuvas intensas de Abril de 1963. 


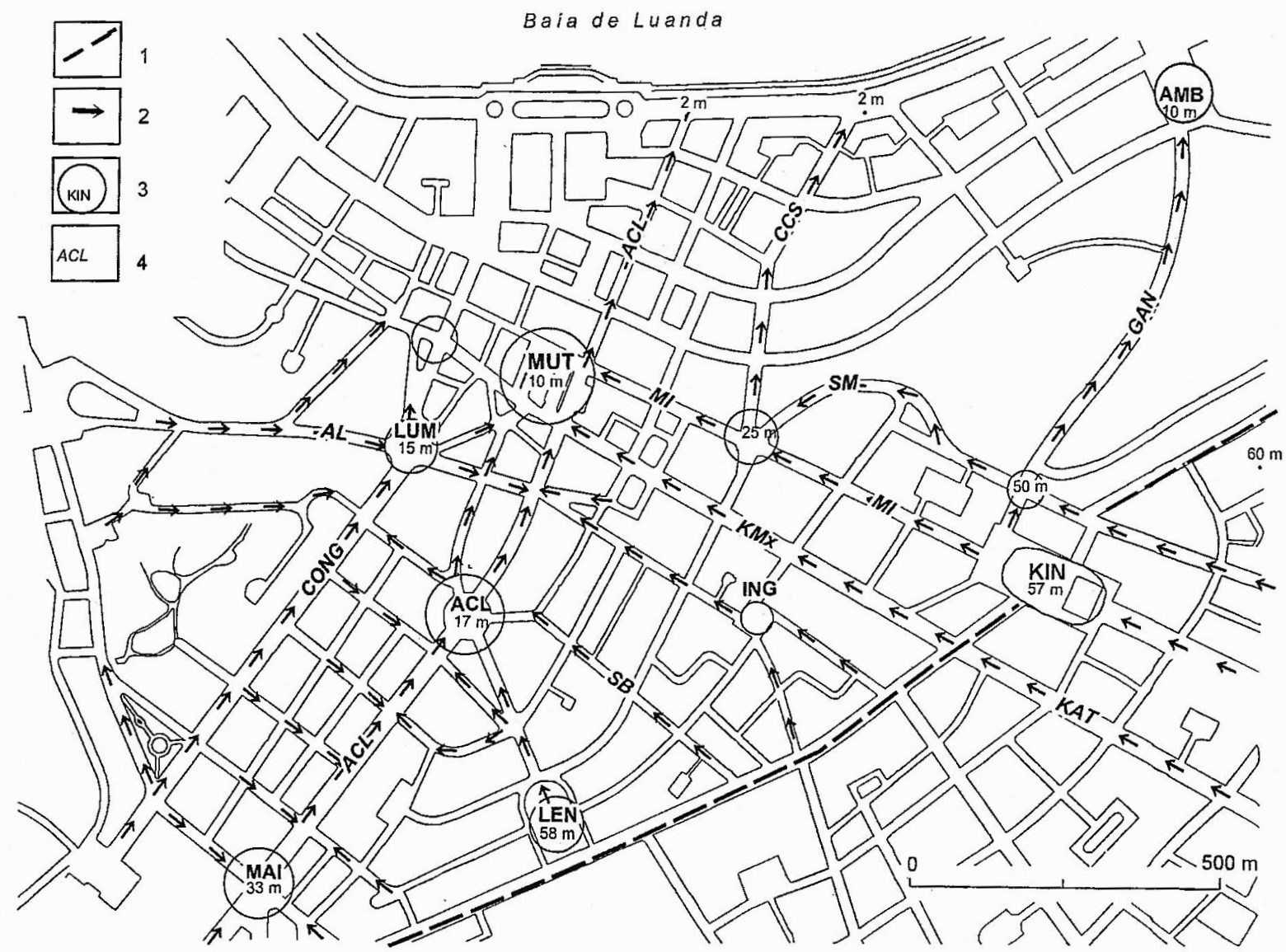

Fig. 6 - Representação esquemática e parcial de bacias (largos ou praças) e canais (ruas) de recepção e circulação de águas pluviais na cidade de Luanda.

1. Limites do planalto e passagem para as escarpas; 2. Direcção de drenagem:

3. Bacias receptoras e distribuidoras de águas pluviais com valores altimétricos aproximados; 4. Abreviaturas de nomes das ruas (ver Quadro I).

área central, das antigas Portas do Mar e suas proximidades, contribuindo os dois para a fixação da disposição radial e concêntrica de ruas, praças e casarios. Mais tarde, aodesenvolver-se sobre o planalto, quase sem obstáculos, com uma mui ligeira inclinação para o mar, a planta tomou outros aspectos, de traçados de maior regularidade, porvezes em quadrícula.

Com o crescimento das áreas urbanizadas os muceques foram sendo expelidos do centro da cidade e empurrados para distâncias cada vez maiores no planalto coberto por areias vermelhas, ainda que alguns núcleos tivessem resistido no meio de conjuntos de edifícios de betão, tijolo e vidro ladeando ruas e praças asfaltadas.Esta impermeabilização dos terrenos, indissociável do processo de modernização da cidade, aumentou, todavia, os riscos de efeitos acelerados das enxurradas por concentração das águas de chuvas tempestuosas à superfície e a sua canalização, com efeitos torrenciais, pelas ruas e edifícios de grande volume (figs. $6 \mathrm{e} 7$ ).

E retomando o excerto do meu livro, utilizado no . programa deste VIII ${ }^{\circ}$. Encontro sobre Riscos Naturais, "muito embora o total da precipitação anual seja baixo, e reduzido o número de dias de chuva, as quedas de Março e Abril correspondem a 60-70 p.100 daquele valore atingem, em regra, uma violência tal que chegam a provocar prejuízos materiais elevadíssimos na área da cidade. Além de afectarem o solo em profundidades que podem ir até aos $2 \mathrm{~m}$, as águas correm bravias pelas barrocas do abrupto, carregadas de massas volumosas de detritos. Descarregadas assim para a parte baixa da cidade, destroem tudo à sua passagem, arrastam automóveis que muitas vezes atiram para a baía, abrem sulcos profundos nas ruas depois de lhes destruírem os pavimentos" empedrados ou asfaltados. Em 1962 e 1963, anos com precipitação 
total da ordem dos $600 \mathrm{~mm}$ e quedas máximas de 50 $-60 \mathrm{~mm}$ de 6 a 8 de Abril, "um dos sulcos abertos" numa calçada declivosa e asfaltada do planalto para a baixa, "media mais de $5 \mathrm{~m}$ de profundidade e os materiais depositados" nos sectores terminais de barrocas, na Cidade Baixa, "chegavam a encobrir automóveis" e os pisos térreos de vários edifícios, penetrando no seu interior por portas e janelas (figs. 4 e 5).

Logo nos primórdios da fundação da cidade, no local de primeira fixação, que foi o morro que mais tarde viria a receber o nome de São Miguel, os primeiros habitantes foram sensíveis aos fenómenos da vulnerabilidade física e de riscos naturais. Numa carta ânua escrita em Luanda, datada de 1602, os padres jesuítas manifestavam o desejo de mudarem do morro, urgentemente, para uma área do planalto mais tarde designada de Cidade Alta, tal como já tinha feito a maioria dos moradores portugueses, deixando "deserto" aquele sítio (o morro) que se ia "gastando" com as "muitas barrocas" que tinha.
A grande penitência que se podia "dar a uma pessoa" era obrigá-la a ir à residência e igreja dos jesuítas, "por o caminho ser ladeira acima"; durante a semana ninguém ia "a ouvir missa", aos domingos "aparecia alguma mas pouca" e à pregação "apenas iam uns tantos que se atreviam a subir as ladeiras íngremes (I. do Amaral, 2000a, pp. 99-100).

Da leitura atenta de outros documentos de padres jesuítas ressaltam, para além da estreiteza do morro, das suas barrocas e das dificuldades de acesso, os resultados negativos do rápido desequilibro imposto a um meio ecológico dotado de vulnerabilidade intrínseca, por uma ocupação humana desregrada do pequeno espaço (logo de início foram feitas diversas doações de chãos, que acabaram por ser objectos de especulação), pelo abate da escassa vegetação, formada sob condições climáticas de semi-aridez, para a obtenção de materiais de construção e lenha, pela abertura de pedreiras nas bancadas calcárias do morro.

Em tempos mais modernos houve que construir muros de suporte e algumas barragens, plantar espécies

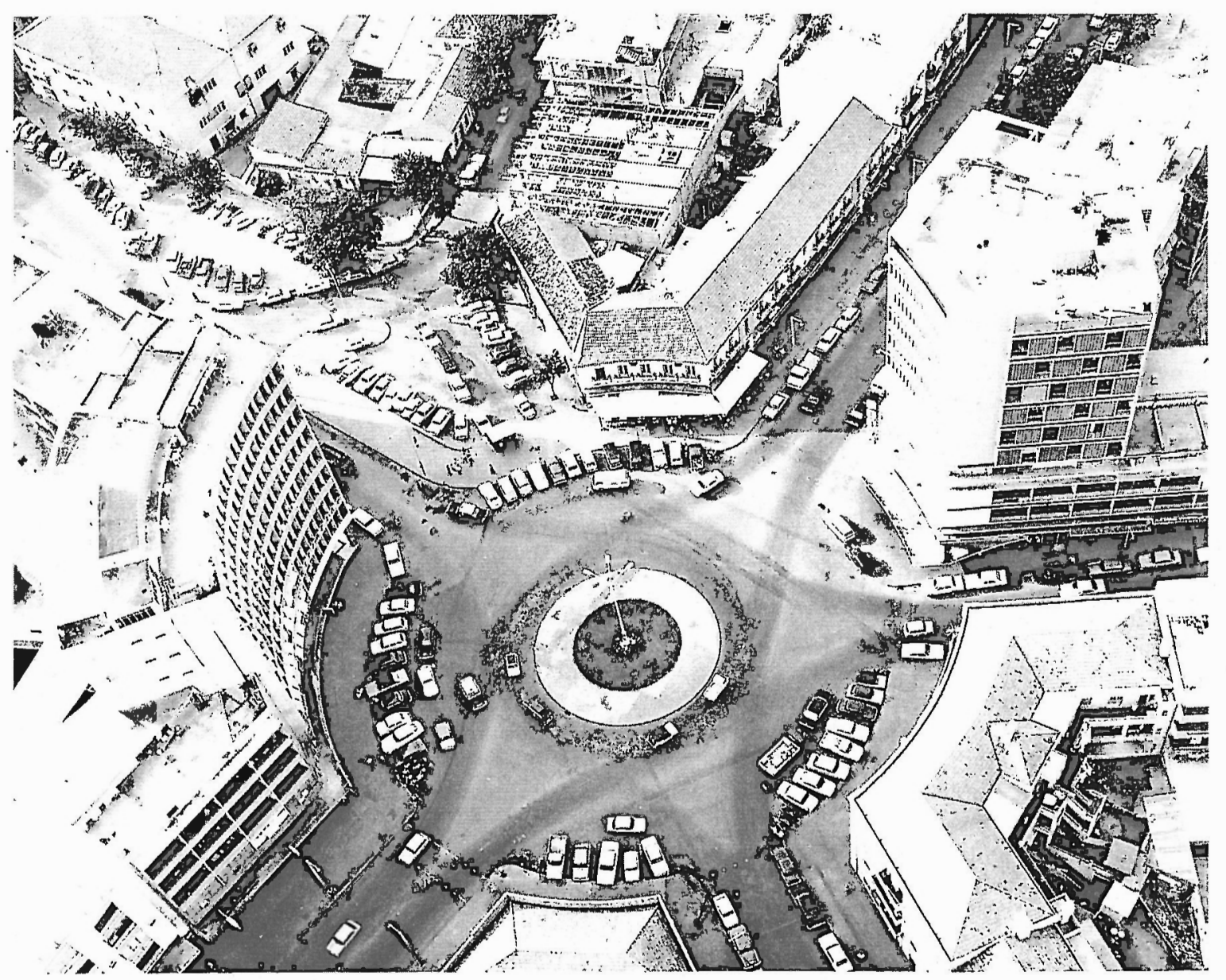

Fig. 7 - O Largo de Amílcar Cabral em que convergem as ruas de várias direcções, canalizadoras de águas pluviais. Na fotografia, o eixo NE-SO é o da rua com o mesmo nome entre a Maianga, no interior, e a Avenida 4 de Fevereiro, que orla a baía. 


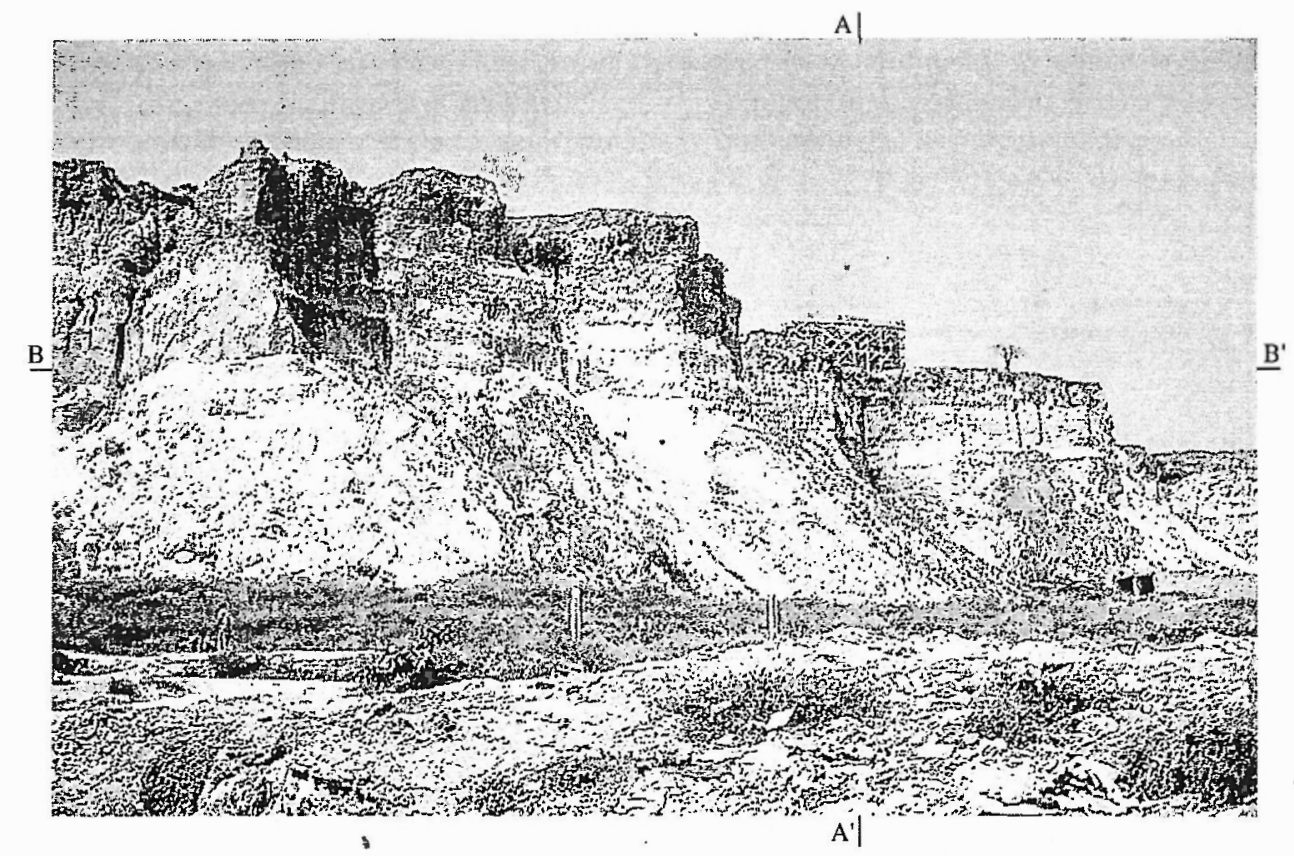

Fig. 8 - Escarpas abarrocadas da Boavista-Porto de Luanda. No cruzamento das linhas AA' e BB' está a estrutura em betão do grande écran do cinema Miramar, ameaçada de queda eminente por recuo de cabeceiras de barrocas activas.

arbóreas e arbustivas para minorarem os efeitos da erosão promotores da progressão do crescimento das barrocas, por erosão regressiva, o seu alargamento e maior ramificação (fig. 3).

O trânsito entre os dois planos da cidade, tendo de vencer as escarpas abarrocadas, mereceram, naturalmente, alguns cuidados dos moradores, pelo menos até meados do século XVIII, como atestam vários manuscritos e plantas, das quais referirei apenas as partes, que aqui interessam, de uma planta e perspectiva de 1755. "As ligações entre a Cidade Baixa e a Cidade Alta faziam-se através de algumas calçadas e ladeiras, a maior parte das quais abria /.../ no bairro dos Coqueiros: a Calçada de Santo António" - conservou a mesma designação pelos séculos fora - "que passava entre os bairros de Escravata o Boy / .../ e dos Remédios; a Calçada que foy, difícil de localizar na planta actual; a Ladeira da Feira Grande" - depois Calçada do Pelourinho, cruzando com a de Santo António; a Ladeira do Boy, também difícil de localizar; e, por último, a Calçada desde os Coqueiros até uma zona entre a Sé desse tempo" - ficava na crista entre o morro de São Miguel e a Cidade Alta, restando dela apenas a torre sineira, englobada no edifício dos Serviços centrais de Meteorologia - "e a Fortaleza de São Miguel. Para os lados do convento dos Carmelitas Descalços", nas Ingombotas, "não havendo a escarpa tão abrupta, as subidas eram muito mais suaves, por vários caminhos" (I. Do Amaral, 1968, pp. 44-46).
A referência a meados do século XVIII resulta dofactode haver documentos que transmitem imagens negativas da cidade, como uma carta do governador D. António da Cunha, de Julho de 1754, em que ela é apresentada num estado geral de abandono e de ruína que a cortina "de barrocas tão profundas que parecia ver-se nelas o centro da Terra" (Idem, pp. 47-48) mais exagerava. Entre os habitantes havia uma grande indiferença pelo aspecto da cidade em que viviam; procuravam desculpar-se, com as chuvas e a má qualidade da terra, pelo abandono e decadência que a maior parte das casas apresentava, mesmo as de frontispício "mais imposante". Nos bairros da parte baixa, como dos Coqueiros e da Nazaré, ou no declive das Ingombotas, as cubatas, dispostas caoticamente em espaços entre sobrados, conventos e habitações menos pomposas, separadas por vielas estreitas e tortuosas, eram, frequentemente, destruídas pelos incêndios e pelas enxurradas.

Com isto chega de recorrer à história, caminho utilizado para mostrar como os problemas de vulnerabilidade e riscos, intrínsecos dos sistemas da natureza local e regional, puderam ser reforçados por acções antrópicas, como muito bem sublinhou o grande Amigo e Colega Professor Fernando Rebelo no seu livro de 2001, Riscos naturais e Acção antrópica, distribuído em princípios do ano seguinte. Na continuação deste trabalho apresentarei, de forma sintética e com ilustrações seleccionadas, para não alongar demasiado o espaço que me foi concedido, aspectos 
geomorfológicos e técnicos de algumas escarpas e barrocas da cidade de Luanda. Consoante os exemplos darei relevo a uns ou outros processos, sem que isso signifique exclusividade relativa a um ou outroconjunto de barrocas, mas apenas uma forma de evitar as repetições.

\section{Barrocas de Boavista-Nazaré-Bungo, voltadas para NNO}

O arco envolve as áreas baixas da Boavista, das instalações portuárias, do Bungo e Nazaré, tendo no cimo, na margem do planalto, também de norte para sul, os muceques de Lixeira, Mota e Sambizanga, o elegante bairro Miramar, com as suas vivendas luxuosas (na actualidade, área escolhida de residência de embaixadores de países estrangeiros e de personalidades angolanas), um lindo cinema ao ar livre dotado de vista sobre o porto (o cinema está hoje ameaçado de derrocada parcial pela erosão regressiva de ravinas) e outras instalações de bom nível, o cemitério do Alto das Cruzes, etc., continuando depois até cerca do cruzamento da Rua Luís de Camões com a Calçada de Gregório Ferreira, duas artérias declivosas e de muito trânsito.

A primeira canaliza as águas de uma bacia antiga do planalto, a lagoa do Kinaxixe (fig. 6), de mui longa tradiçãoe que eu ainda conheci, secada e transformada anos mais tarde na Praça dos Lusíadas, mais conhecida por Maria da Fonte, dada a escultura monumetal de uma mulher empunhando bem alto uma longa espada, logo associada à figura lendária com aquele nome, colocada nocimo do monumento dedicado aos mortos da Primeira Grande Guerra. Da mesma bacia saíam águas que as ruas de Mousinho de Albuquerque e de Nossa Senhora da Muxima, abertas no sentido descendente da escarpa, passaram a canalizar.

Note-se que tenho utilizado a toponímia antiga, mas ela foi substituída por outra depois da Independência de Angola. Assim, aqueles "muceques", com novas delimitações, passaram a bairros ou municípios, à Rua Luís de Camões sucedeu a Avenida da Missão, a de Gregório Ferreira é hoje de Cirilo da Conceição Silva, Kinaxixe-Praça dos Lusíadas voltou a ser Largo do Kinaxixe, a Rua de Mousinho de Albuquerque adquiru o nome de Rua Marechal Broz-Tito e a de Nossa Senhora da Muxima manteve o nome (fig. $6 \mathrm{e}$ quadro I). Por isso mesmo, a partir daqui darei as duas designações, a antiga e a actual, separadas por um traço; no caşo de nomes mantidos, claro que haverá apenas esse.

Uma vez que me referi a Kinaxixe como bacia distribuidora de águas, e também receptora, é oportuno acrescentar algumas notas sobre outras bacias com características idênticas em vários locais da cidade, que a urbanização mais evidenciou ao adaptar-se às formas e desníveis topográficos. Sem esgotar a matéria,

\begin{tabular}{|l|l|l|}
\hline \multirow{2}{*}{ Abreviaturas } & \multicolumn{2}{|c|}{ Nomes dos largos e ruas } \\
\cline { 2 - 4 } & Largo do Kinaxixe & \multicolumn{1}{c|}{ Antigos } \\
\hline KIN & Rua Gamal Abdel Nasser & Rua de Pinheiro Chagas \\
\hline GAN & Praça do Ambiente & Nazaré \\
\hline AMB & Rua de Na..Sa da Muxima & Rua de Na S $^{\text {a }}$. da Muxima \\
\hline SM & Rua da Missão & Rua Luís de Camões \\
\hline MI & Rua Cirilo Conceição Silva & $\begin{array}{l}\text { Calçada de Gregório Ferreira-Rua } \\
\text { do Vereador Castelbranco }\end{array}$ \\
\hline CCS & Praça da Mutamba & $\begin{array}{l}\text { Muatmba-Largo do Almirante } \\
\text { Baptista de Andrade }\end{array}$ \\
\hline MUT & Ruas Karl Marx e Rei Katyavala & $\begin{array}{l}\text { Ruas de Vasco da Gama e do } \\
\text { Coronel Artur de Paiva }\end{array}$ \\
\hline KMx e KAT & Largo Lenine & Largo do Dr. Alves da Cunha \\
\hline LEN & Rua do Dr. Alves da Cunha & Idem \\
\hline ACU & Largo da Maianga & Idem \\
\hline MAI & Largo e Rua Amílcar Cabral & $\begin{array}{l}\text { Largo e Rua de Serpa Pinto Rua } \\
\text { de Pereira Forjaz }\end{array}$ \\
\hline ACL & Rua Samuel Bernardo & Rua de Fernão de Magalhães \\
\hline SB & Largo das Ingombotas & Idem \\
\hline ING & Rua Guilherme Pereira Inglês & Rua de Barbosa Rodrigues \\
\hline GPI & Largo do Lumege & Largo de D. Afonso Henriques \\
\hline LUM & Largo Josina Machel & Largo đe Ramada Curto \\
\hline JM & Rua do Congresso & Rua Álvaro Ferreira \\
\hline CONG & Rua Alberto Lemos & Rua de Santo. António \\
\hline AL & & \\
\hline
\end{tabular}




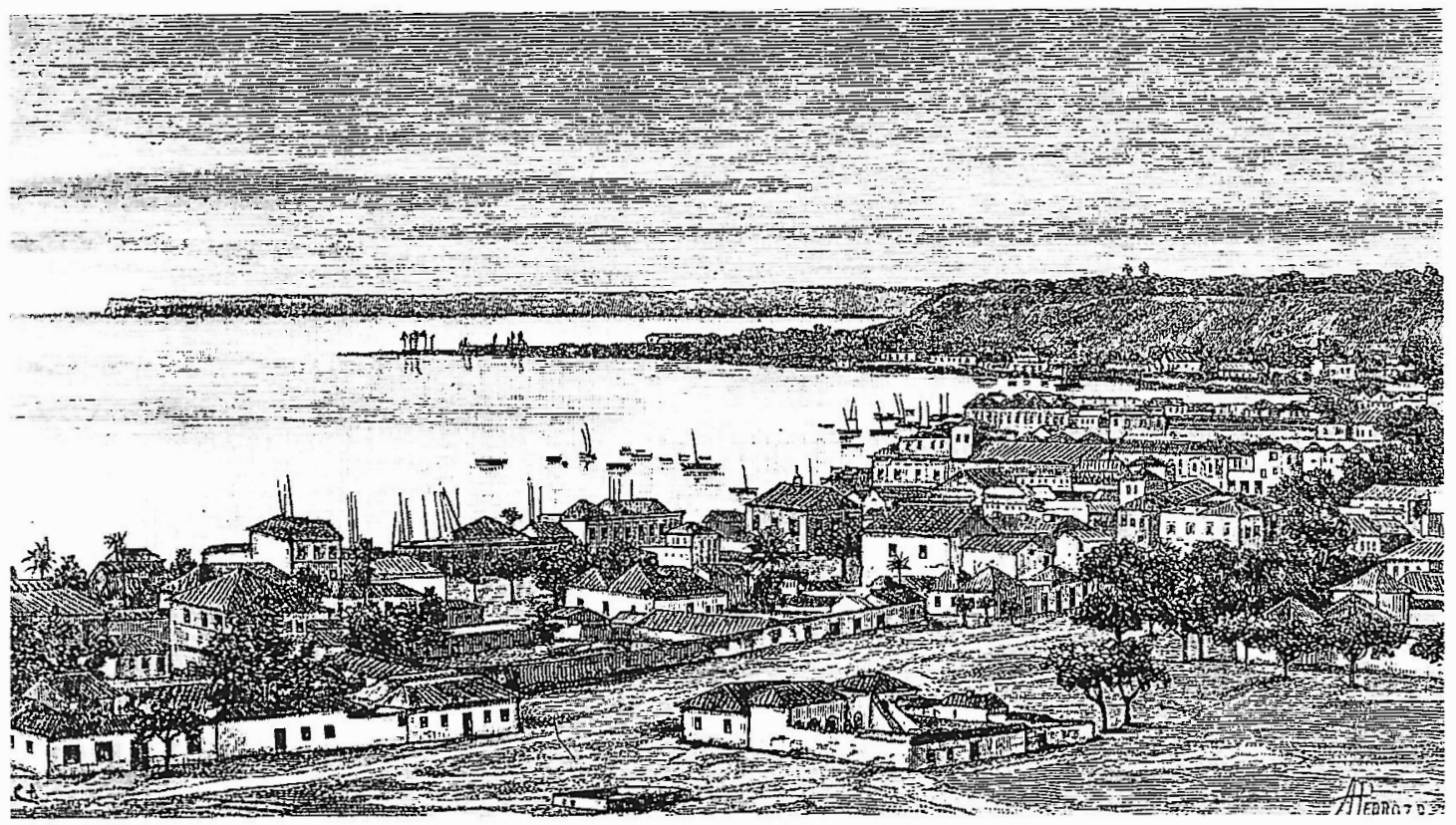

Fig. 9 - Vista parcial de Luanda em 1884. No primeiro plano a Cidade Baixa: no segundo, as escarpas abarrocadas da Boavista, e no terceiro, as arribas da Ponta das Lagostas.

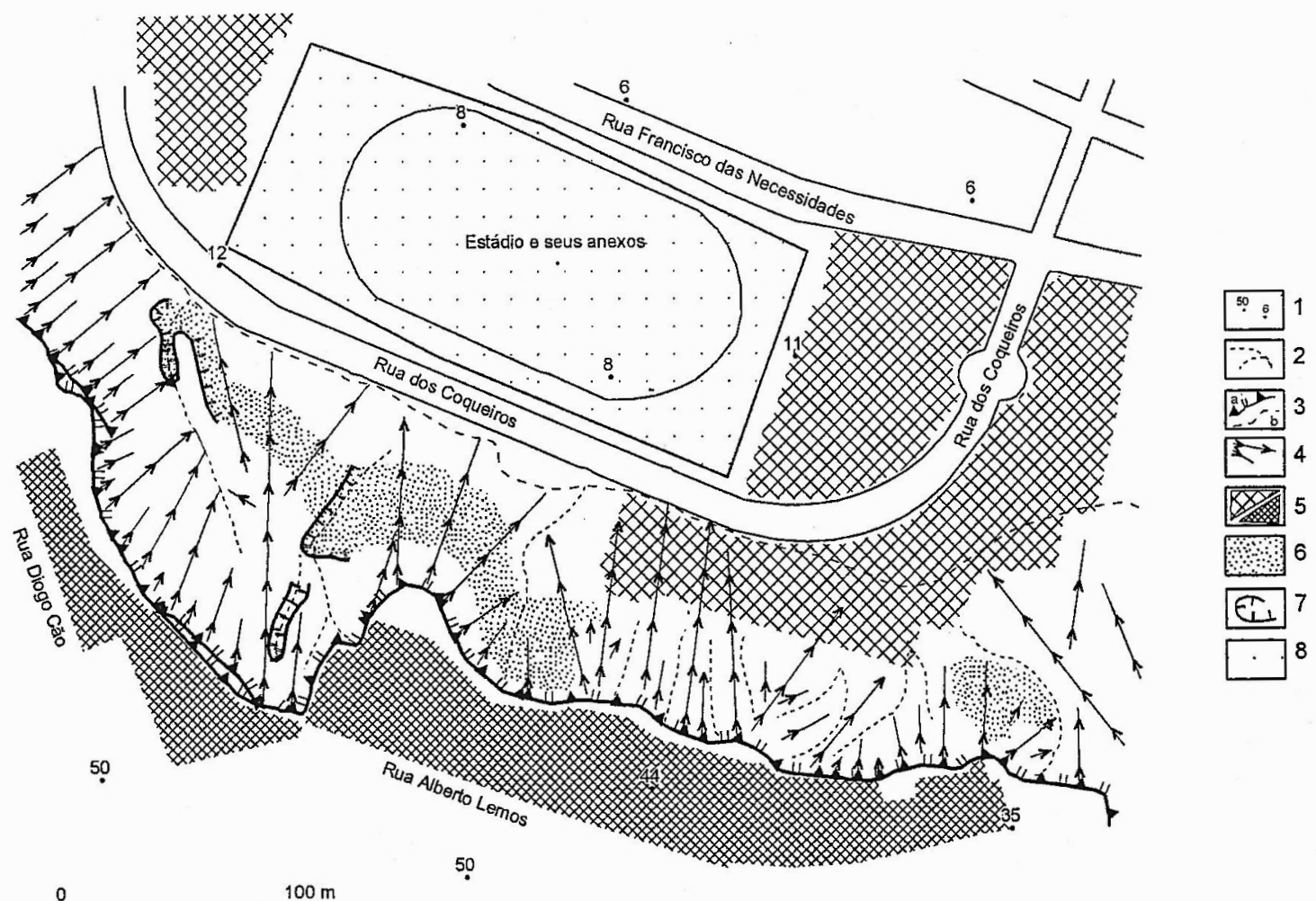

Fig. 10 - Esboceto geomorfológico das escarpas abarrocadas dos Coqueiros.

1. Altitudes aproximadas; 2. Exemplos de algumas linhas de água; 3. Cornijas no alto das vertentes escarpadas e a tracejado os seus limites inferiores; 4. Alguns declives gerais; 5 . Manchas de casario da Cidade Alta e da Cidade Baixa, isto é, no topo e na base das escarpas abarrocadas; 6. Exemplos de derrames de areias; 7. Barrancos, porventura ligados a canais perfurantes: 8. O Estádio dos Coqueiros e seus anexos. 
utilizo alguns exemplos apresentados, muito esquematicamente, na figura 6 e que deverão ser lidos com os elementos do quadro I.

Torna-se fácil ver que tais bacias, salvo a do Kinaxixe, estão para norte dos limiares do planalto sublinhados, a oriente, e parcialmente a sul, pelos traçados da Rua Marechal Broz-Tito, antiga Rua de Mousinho de Albuquerque, e da Avenida Lenine, antiga Avenida de Brito Godins; mais a sul eles são menos bem definidos, em consequência da abertura

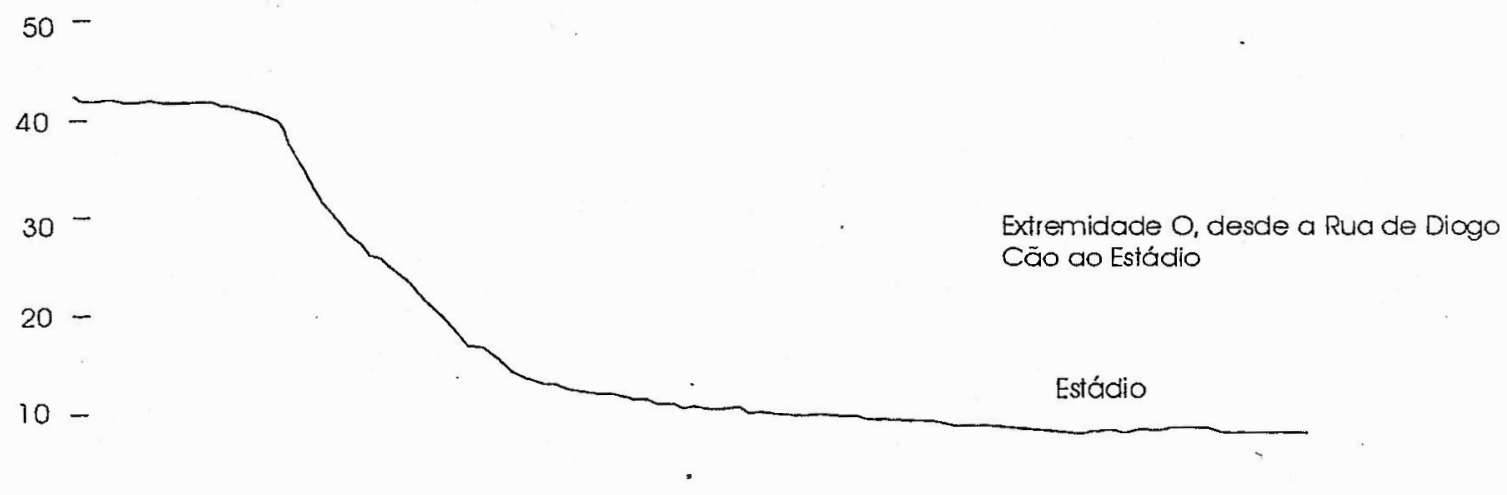

0

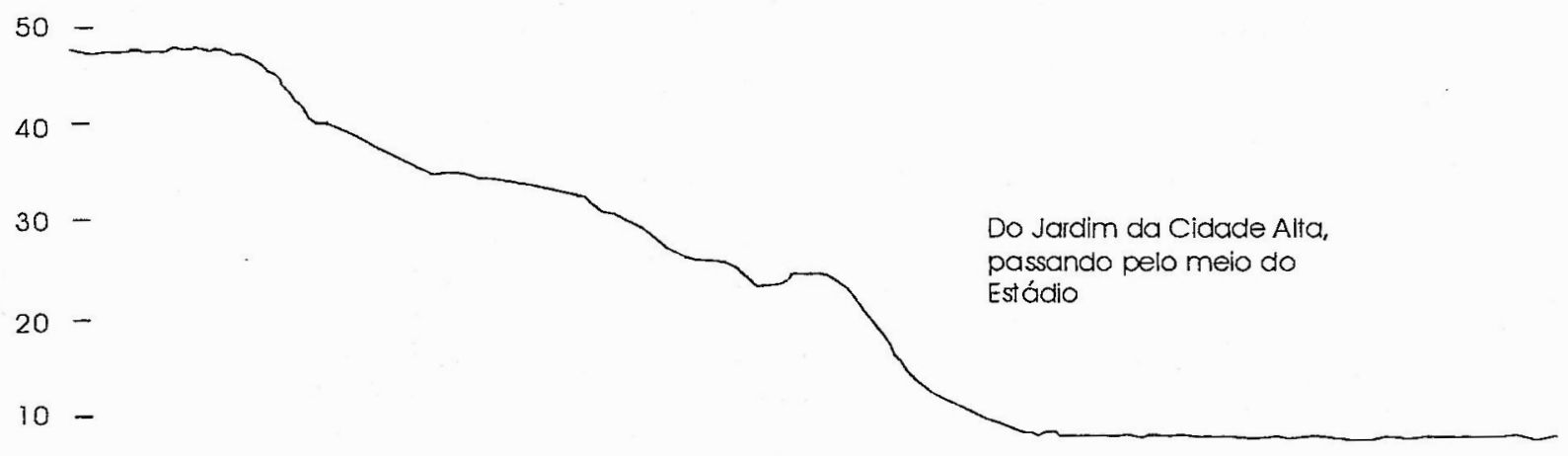

0

$50-$

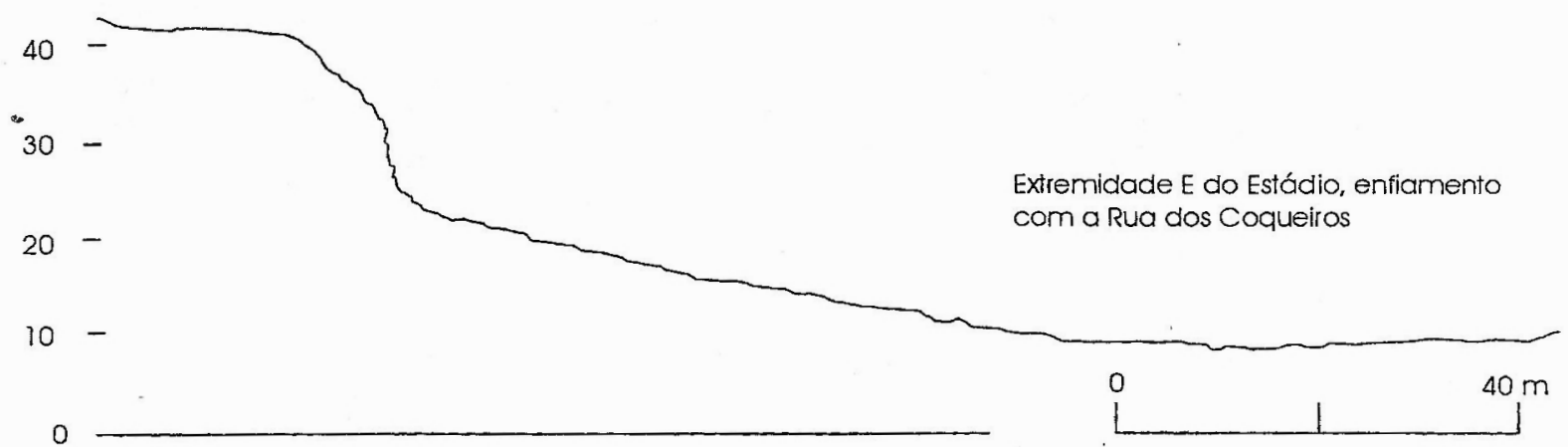

Fig. 11 - Perfis topográficos das escarpas abarrocadas dos Coqueiros, de oeste para este. 


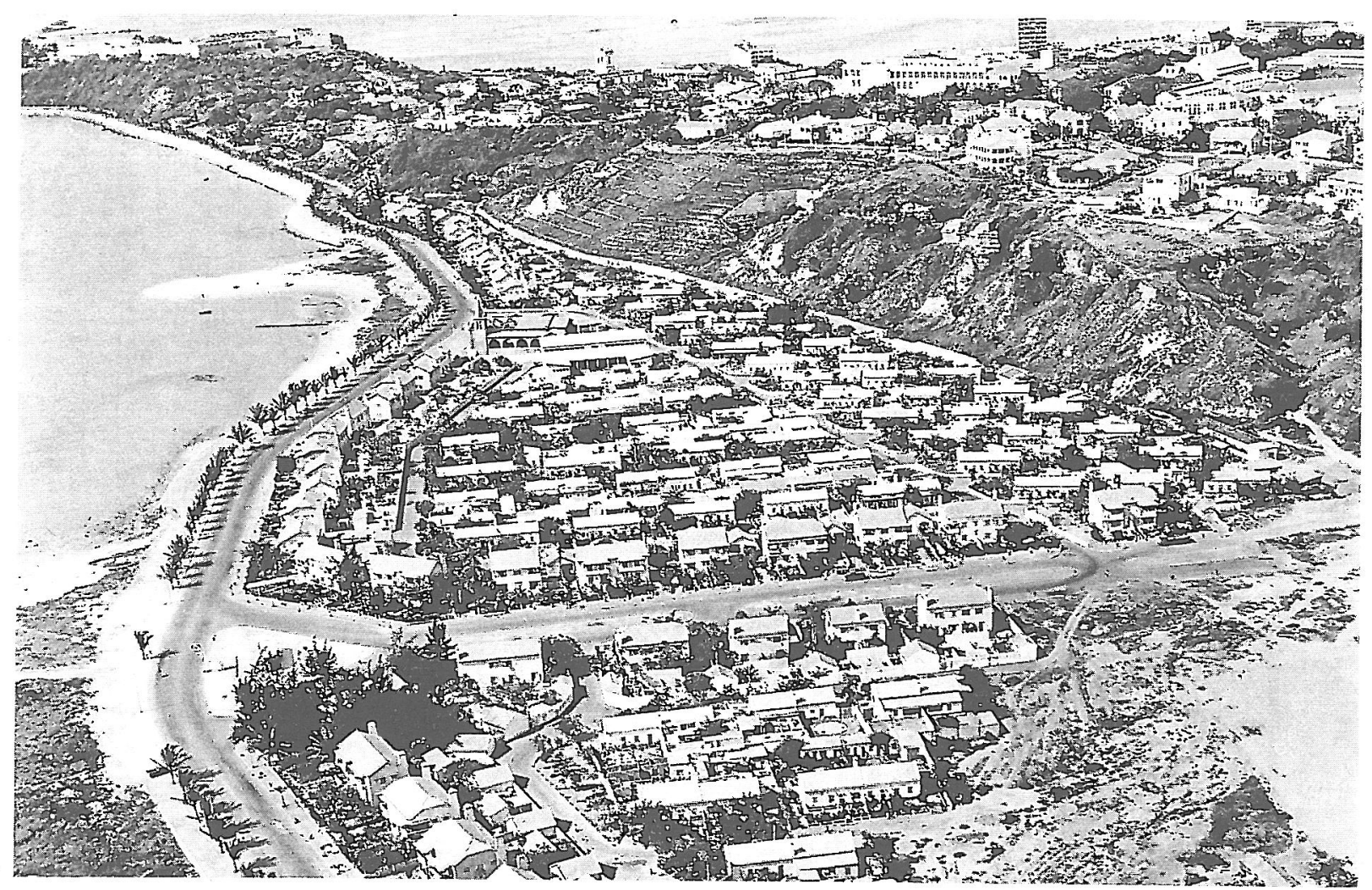

Fig. 12 - Escarpas abarrocadas e praias desde a Fortaleza ao Bairro da Praia do Bispo. As escarpas separam a Cidade Alta da Cidade Baixa. $\mathrm{Na}$ extremidade esquerda sinais evidentes de obras de regularização de declives.

e alargamento do vale da Maianga; e a ocidente, os limites são dados pela Cidade Alta. Todo o território das bacias inclina para a orla de antigas praias e aterros sobre os quais assentou a Avenida Marginal- Avenida de Paulo Dias de Novais, hoje Avenida de 4 de Fevereiro. A baía é o plano de convergência de toda essa escorrência urbana. Na figura houve ainda a preocupação de inscrever valores altimétricos aproximados, os quais relevam as posições escalonadas das bacias, desde as mais altas (coincidentes com os largos de Kinaxixe, Lenine, Maianga, etc.) às situadas em terrenos mais baixos (dos largos da Mutamba, do Ambiente, etc.).

Entre os exemplos mais interessantes de adaptação de ruas e praças ou largos à topografia original está a Rua Amilcar Cabral, ex-Serpa Pinto continuada pela Pereira Forjaz, longa desde o Largo da Maianga no interior até à baía, orientada SSO-NNE que, passando pelas bacias do mesmo nome e da Mutamba se dirige para NNE. Na sua maior parte esta via foi implantada num antigo alvéolo fluvio-torrencial, recebendo afluentes de ambos os lados, como testemunham as ruas cruzadas do sistema viário.

De todas as bacias aqui apresentadas a da Mutamba continua a ser colectora e distribuidora da maior importância e pena é que a antiga praça, ampla e ajardinada, tivesse sido encurtada ao construir-se, na parte ocidental da sua área, o enorme edifício dos Serviços de Fazenda-Ministério das Finanças, sem se atentar nos riscos de inundações e prejuízos ligados às torrentes formadas em meses de chuvas fortes (Março e Abril) e que convergem nela. Como se pode ver na figura 6 , assim sucede com dois dos mais importantes sistemas torrenciais da área que escolhi como amostra.

Retomo então o que escrevia sobre as barrocas da Boavista-Nazaré-Bungo. Olhando para os perfis das vertentes (figs. 8 e 9), podem distinguir-se, não obstante a complexidade dos seus traçados, três sectores principais a partir do planalto coberto de areias vermelhas sobre leitos de burgaus com testemunhos evidentes de rolamento marinho: um abrupto próximo da vertical, de face irregular, resultando este aspecto dos efeitos da erosão diferencial nas camadas sedimentares, umas mais consolidadas (arenitos avermelhados), outras menos (areias de tons claros); um troço longo de vertente, menos declivoso, com um perfil complexo, primeiramente convexo, depois tendendo a côncavo ou rectilíneo, modelado sobre escombros de blocos e detritos mais pequenos derrocados ou deslizados das faces abruptas, muitas vezes enroupados por alteritos argilosos; e, 
territorium 9.2002

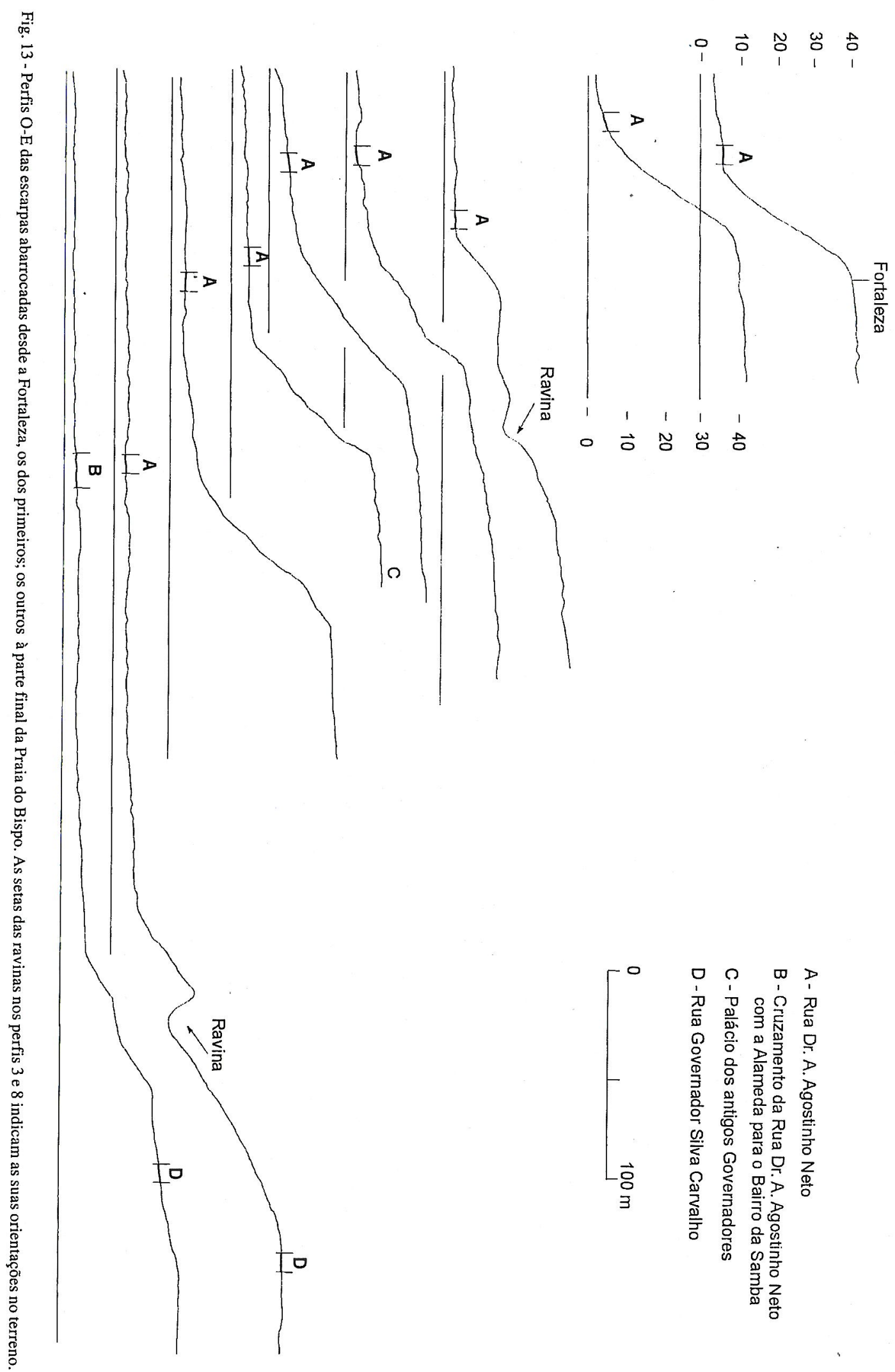




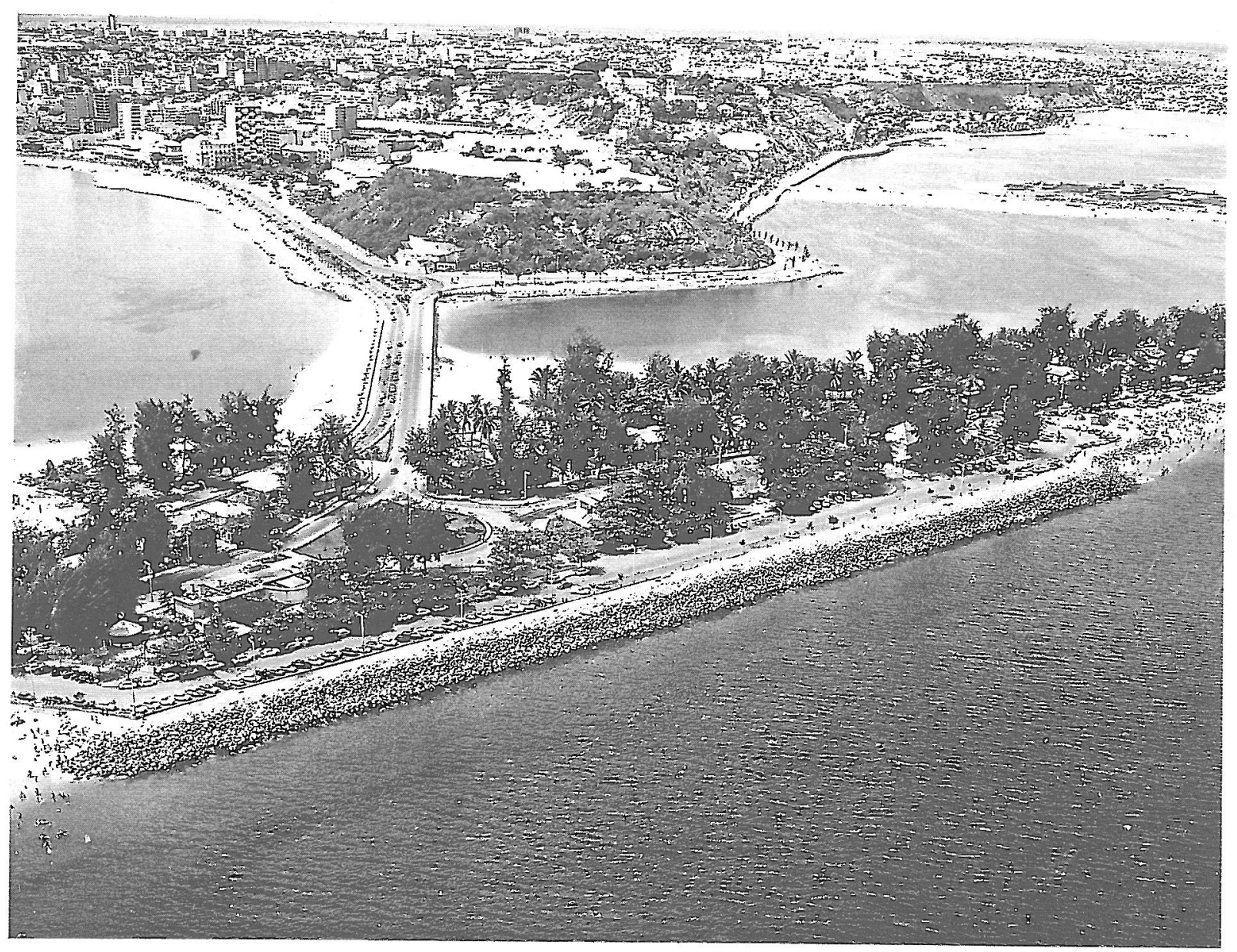

Fig. 14 - A Ilha de Luanda, a ponte de cimento e o morro da Fortaleza. No primeiro plano as praias oceânicas cobertos por blocos rochosos e de betão, para evitar o arrastamento das areais pelas correntes marítimas; no segundo, as baías de Luanda, à esquerda, e de Samba, à direita, podendo ver-se nesta a Chicala II nos anos de 80-90 do século passado; e no terceiro, vista parcial da cidade.

no extremo, uma concavidade, na passagem para a superfície de sopé, uma antiga praia, que funciona como nível de base local.

De uma maneira geral, os escombros escondem margas e alguns bancos calcários intercalados que não só fornecem detritos, como contribuem para as suas deslocações. Por exemplo, as primeiras, quando afloram, mostram alterações resultantes de variações de fenómenos térmicos e hídricos, relacionados com as condições climáticas, que favorecem desmoronamentos e deslizamentos de materiais assentes nelas. As superfícies que delimitam os cones de escombros, quer estabelecidas sobre clastos (blocos de variadas dimensões e outros elementos menores) em regime seco, quer constituídas por revestimentos argilosos, têm deformações elásticas resultantes de vários factores, de que recordarei alguns: tamanhos e formas dos blocos rochosos e dos fragmentos menores, suas mudanças de posições (rotação e translação) sob a acção da gravidade, pela presença de materiais argilosos, ou sob forte intensidade e impacto das quedas pluviais, graus de compactividade dos elementos rochosos, influências da vegetação, quando ela existe (penetração de raízes), e, naturalmente, as intromissões humanas, etc. (I. do Amaral, 2000b, pp. 11-12).

As barrocas crescem e testemunham a forma mais destrutiva e, certamente, a mais espectacular da erosão regressiva acantonada em canais de escoamentos líquidos ou pastosos e quando estes são do tipo torrencial. O seu crescimento e multiplicação resultam não apenas de causas naturais, de que se distinguem os efeitos da erosão regressiva, da queda de materiais por gravidade, quer em condições secas, quer pela presença de água ou da fluidez de certas camadas, do desenvolvimentos de canais tubulares perfurantes, etc. mas também de acções antrópicas, sobretudo quando elas foram e continuam a ser importantes. O problema geomorfológico está em separar os efeitos 
territorium 9.2002

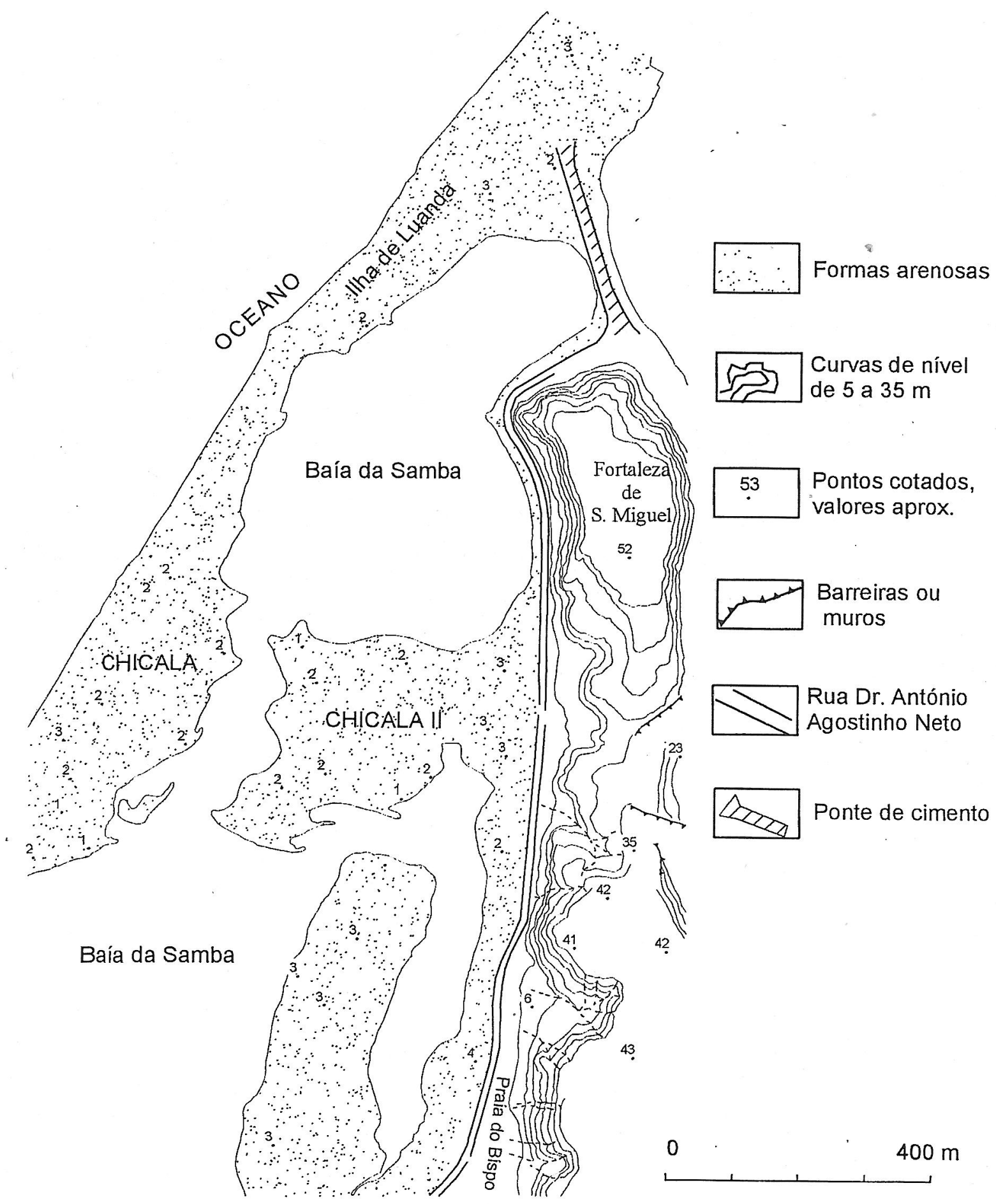

Fig. 15 - A Ilha na sua parte da Chicala, a Chicala II, as baías e as escarpas abarrocadas da Fortaleza à Praia do Bispo. 
climáticos dos de actividades humanas que promovem a aceleração da erosão e o caso da barrocas da Boavista ilustram bem isso pois elas foram alvo de desbastes importantes há cerca de meio século, quando delas se extraíram quantidades enormes de materiais, sobretudo areias, para as obras de construção do porto, em território da sua base, na Ponta da Mãe Isabel.

Modificado o seu estado de equilíbrio sustentável, devido ao encurtamento da largura do seu nível de base e do comprimento de muitas delas pelos cortes para a exploração de materiais destinados aos fins mencionados, a adaptação às novas condições continua a acelerar os processos de erosão regressiva, materializada pelo recuo das cristas de barrocas, o que põe em perigo estradas importantes, como a da Circunvalação, eixo fundamental de ligação da cidade com o norte do País, e construções na buorda do planalto, como serve de exemplo o risco de desmoronamento eminente de parte da estrutura do grande écran e palco do cinema Miramar (fig. 8), uma vez minada a folga de sustentação. Guardo outros processos de evolução das escarpas e das barrocas para o que vem a seguir.

\section{Barrocas dos Coqueiros-Fortaleza, voltadas para NNE}

Dispõem-se em semi-circulo aberto para norte mas fechado nos outros lados (fig. 10). Na sua parte cimeira o arco está delimitado pelas construções que ladeiam a Calçada do Pelourinho-Calçada Katádi a leste, que no topo cruza com a Calçada de Santo António-Rua Domingos Tehakahanga, na transição para o planalto; a Rua de Luís Serrão, Calçada de Santo António-Rua Alberto Lemos (com o Jardim da Cidade Alta e a Praça do Palácio-Praça do Povo) a sul; e a Rua de Diogo Cão (com o Palácio do Governo e área defronte dele, ajardinada e com miradouro) a oeste, conservada a designação até à ponte que dá acesso à Calçada de São Miguel e Fortaleza do mesmo nome. Entre o Palácio e a Fortaleza, um troço da Rua de Diogo Cão corre sobre o cimo aplanado de uma crista ou cutelo estreito, de 180-200 m nos poucos sectores mais largos e $50-60 \mathrm{~m}$ nos mais estreitos, que separa o arco de barrocas dos Coqueiros do arco da Praia do Bispo, do qual me ocuparei mais adiante.

$\mathrm{Na}$ base os limites são marcados pelo complexo do estádio dos Coqueiros e por outras construções que bordejam a rua com o mesmo nome. A maior distância, em linha recta, da Rua de Diogo Cão à Calçada do Pelourinho-Calçada Katádi, tidos como limites oeste e leste, é de cerca de $610 \mathrm{~m}$ e a registada entre a base do arco-Rua dos Coqueiros e a Rua de Ferreira de Almeida-Rua Francisco das Necessidades ronda os $150-200 \mathrm{~m}$; a baía fica-lhe a 450-500 m. Como as altitudes no planalto são de $49-50 \mathrm{~m}$ e as do estádio de 7-8 m, as escarpas têm, na vertical, alturas relativas de um pouco mais de $40 \mathrm{~m}$. Nas figuras 10 e 11 um esboceto geomorfológico e alguns perfis traçados de oeste para leste, ilustram os principais aspectos do arco de barrocas dos Coqueiros, evitando assim o alongamento com palavras escritas.

Desculpar-me-ão os leitores deste texto se volto a recordar momentos deleitosos da minha infância e juventude, como assinalei a propósito da Ilha. O casarão de família na cidade ficava, exactamente, no cruzamento das ruas dos Coqueiros e de Ferreira de Almeida, por um lado, a poucos metros da entrada mais utilizada para o estádio, onde, com gente da minha idade, pratiquei futebol e outras modalidades desportivas, e a rua e a entrada tinham movimento desusado em dias de jogo da bola; por outro lado, as barrocas, que ficavam a dois curtos passos, eram locais preferidos de criação de fantasias lúdicas, ora de "lutas entre cowboys e índios" nas terras agrestes estadounidenses, ora de "batalhas e assaltos de corsários e piratas" no mar das Caraíbas (Henry Morgan, Francis Drake e muitos mais) ou do Sueste da Ásia (especialmente Sandokan, de Emlio Salgari), influenciadas pelos filmes e livros de aventuras. As armas, riffles, lanças e espadas, arcos e flechas, consoante os casos, eram feitos de canas ou de pedicelos das folhas de mamoeiros e bocados de bordão, utilizando deste a casca flexível e o miolo brando e de fácil modelação; os burgaus das cascalheiras eram a metralha, as colunas e pináculos de areais e arenitos serviam de anteparos e os canais e buracos perfurados e alargados nos materiais mais friáveis, tidos naquela altura como "enormes", serviam de esconderijos e fortalezas.

Estava longe de imaginar que, um dia, muito mais tarde, veria as "minhas barrocas" com outros olhos, os de geomorfólogo interessado em observar e explicar a sua génese e evolução. Do ponto de vista da litologia, de um modo geral, predominam, a partir do topo, areias amarelo-avermelhadas contendo instrumentos líticos, areias com núcleos ferruginosos, areias claras com manchas avermelhadas, leitos de burgaus de morfometria marinha e margas com carapaças ferruginosas. Alguns estratos arenosos, por fenómenos de cimentação, quer ferrosa, quer carbonatada, ganharam certa solidez e resistência aos processos erosivos, formando camadas de alguma dureza e pequenas palas salientes, ou dando reforço a alvéolos abertos nas vertentes e a caneluras ou canais perfurantes, horizontais e noutras posições.

Perante este quadro litológico tudo leva a pensar que a aparente perpetuidade do arco de barrocas dos Coqueiros se deve ao facto de ele estar "aprisionado" entre obstáculos morfológicos bem definidos e 
territorium $\quad 9.2002$
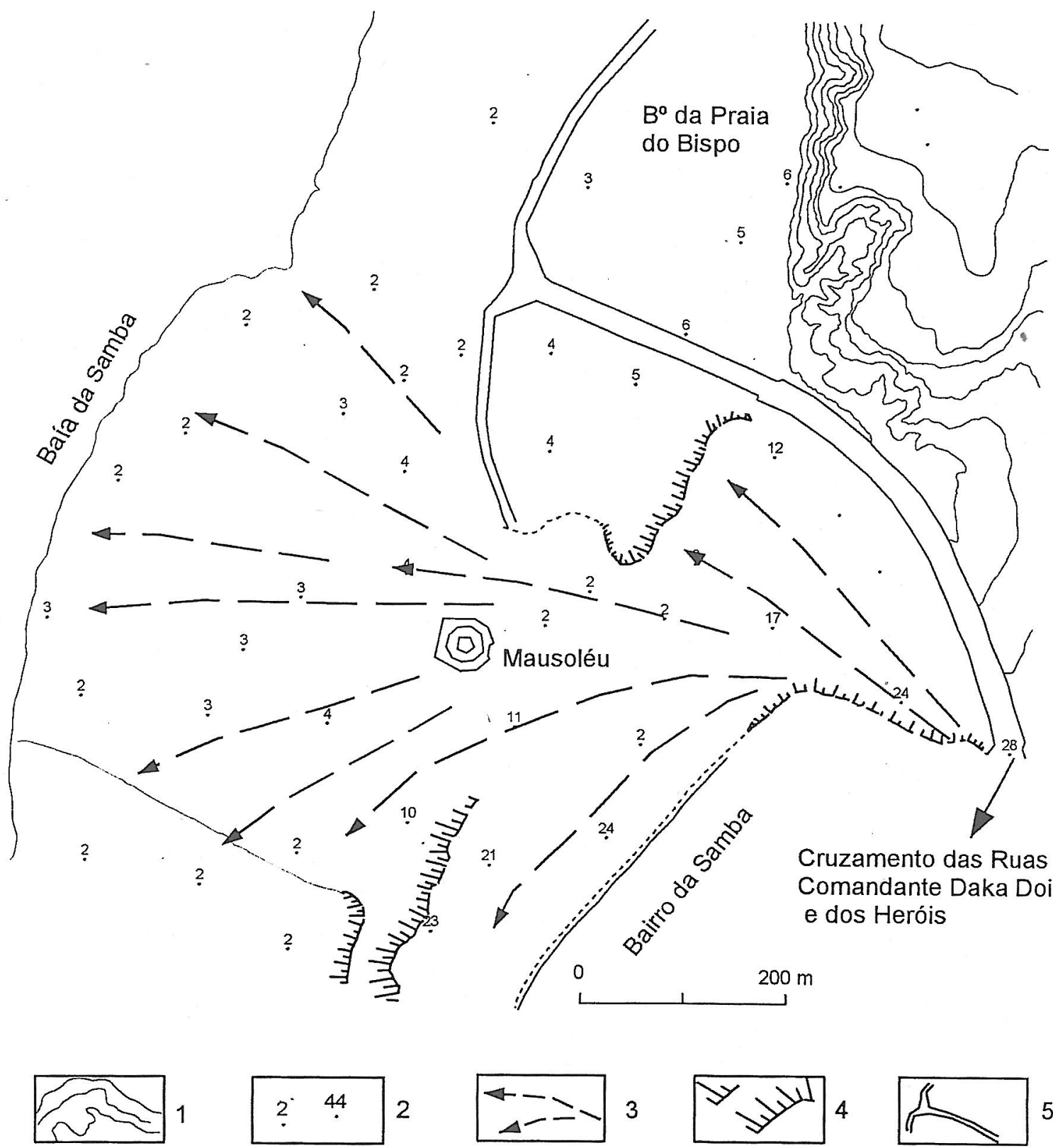

Fig. 16 - Parte terminal das escarpas abarrocadas da Praia do Bispo e plano inclinado da Mausoléu do Dr. A. Agostinho Neto. 1. Curvas de nível de $5 \mathrm{em} 5 \mathrm{~m}$, a partir de $10 \mathrm{~m} ; 2$. Pontos cotados, valores aproximados; 3 . Declives gerais do plano inclinado criado pela construção do Mausoléu e suas proximidades; 4. Degraus ou desníveis; 5. Cruzamento da Rua Dr. A. Agostinho Neto, sentido norte-sul, com a Alameda arqueada para sueste entre os bairros da Praia do Bispo e da Samba. 
construções humanas importantes, no topo, na base e lateralmente, conforme foi mencionado em local anterior. É como se tratasse de um amplo sistema entrópico: as barrocas não deixam de se modificar, por processos físicos, como os da deslocação de materiais (queda e deslizamento de blocos, derrame de areias) e os resultantes de variações da amplitude térmica, intensos nas vertentes de maiores pendores; por processos erosivos, de natureza essencialmente pluvial, sobretudo quando as águas se concentram em torrentes intermitentes; por processos químicos, desencadeados pela humidificação geral e alteração de alguns elementos constituintes das rochas; pela intervenção humana. Mas tudo fica contido nos limites que encerram o arco.

A propósito de humidade atmosférica é preciso não esquecer que, em primeiro lugar, a barreira de barrocas abre, francamente, para o mar, captando o vapor de água, que penetra nelas por diversas vias, isto é, vazios ou poros, pequenas fissuras, fracturas, fendas de dissecação e outras faixas de fraqueza litológica; e que, em segundo lugar, a semi-aridez regional é de um tipo muito particular, relacionada com os fenómenos de upwelling com sede na corrente fria de Benguela, fornecendo grandes quantidades de vapor de água para a atmosfera, mesmo nos meses mais secos do ano, em que não se desencadeiam os mecanismos da precipitação (I. do Amaral, 1985, pp. 6-8). Na área de Luanda o valor anual da humidade relativa ronda os $80 \mathrm{p} .100$, sendo os meses de cacimbo, isto é, de tempo menos quente e seco, justamente, os de maiores quantidades: de Maio a Outubro, com quedas pluviométricas nulas ou quase nulas e temperaturas do ar um pouco abaixo da média anual, que é de cerca de $25^{\circ} \mathrm{C}$, os valores da humidade relativa estão acima de 80 p. 100; de Novembro a Fevereiro-Março, eles ficam entre 75 e 79 p.100. Março e Abril são os que registam, normalmente, os maiores valores de precipitação, chegando os dois a somar um pouco mais da metade do total anual.

Neste sentido cabe incluir aqui uma pequena nota sobre os processos de abertura e alargamento de caneluras ou canais perfurantes, pois também contribuem para a modificação das formas do relevo. A penetração de água nas formações rochosas graças às vias já referias, antes que as sua paredes intumesçam e fechem, permite que essa água de percolação remova partículas sólidas de vários tamanhos, de argila a dimensões maiores, dando assim lugar à abertura de condutas tubulares que podem atingir grandes profundidades. Uma vez iniciadas, as condutas são alargadas pelas correntes fortes de águas pluviais, transformando-se em canais activos. As águas, se encontrarem um nível impermeável, podem formar pequenos aquíferos, situados, muitas vezes, a diversas alturas, que contribuirão para a meteorização química das rochas e subsequente enfraquecimento de níveis internos; no caso dos canais serem cortados pelos desbastes de vertentes, elas correm para fora.

Os resultados destes processos, sucintamente delineados, podendo também ser visíveis nas barrocas dos outros arcos, são demasiado notórios nas dos Coqueiros, explicando-se assim as "grutas" e canais, as palas e outros elementos das vertentes.

\section{Barrocas da Fortaleza-Praia do Bispo-Samba, voltadas para $O$}

Tendo escrito, em páginas anteriores, algumas notas sobre as vertentes e barrocas do morro da Fortaleza de São Miguel, pouco mais acrescentarei sobre elas e ocupar-me-ei, sobretudo, das escarpas abarrocadas da Praia do Bispo-parte norte da Samba e suas adjacências (figs. 12 a 15).

Começo por relevar o notável alinhamento N-S destas escarpas voltadas para ocidente, numa distância de cerca de $1.600 \mathrm{~m}$, medidos desde a ponta daquele morro ao local onde a linha inflecte para leste, sobranceiro à Alameda aberta entre os bairros da Praia do Bispo e da Samba. Na sua parte inicial as vertentes e barrocas foram submetidas a obras de. regularização, pela construção de muros de suporte, de barragens, de aterros e socalcos, e pela plantação de espécies arbóreas e arbustivas, o que lhes dá, numa certa distância, um comportamento de equilíbrio. Todavia, quase se pode dizer o mesmo das vertentes a descoberto, como mostram os perfis projectados (fig. 13), salvo nos casos em que as barrocas escavam mais activamente.

Pelo lado sul o morro da Fortaleza separa-se do resto por um estrangulamento O-E que os primeiros habitantes da cidade aproveitavam como caminho mais rápido e confortável entre os Coqueiros e a Praia do Bispo. Posteriormente foi aberta a Rua de Franciso do Soveral, hoje Rua José Pedro Tuca, passando sob a ponte de Diogo Cão, que liga a rua do mesmo nome à Calçada de São Miguel e Fortaleza. Enquanto as escarpas do morro se mantêm muito próximas das águas da baía, as da Praia do Bispo, estão bastante afastadas delas. No decorrer dos tempos, por causas diversas, foi aumentando a orla de terrenos baixos, com 1,5 a $3 \mathrm{~m}$ acima das águas da baía, tendo hoje a maior expressão no apêndice da Chicala II e na manga que cresce um pouco a sul, individualizada a partir do areal defronte da igreja do bairro (figs. 14 e 15).

Ambas têm crescido de forma rápida e a primeira, na frente da Rua José Pedro Tuca, foi sendo ocupada por gente que tem transformado a área num muceque denso, de construções desordenadamente implantadas, sem qualquer preocupação de um esquema de arrua- 
mentos, salvo a chamada Rua da Chicala, quase no enfiamento da Rua José Pedro Tuca. Mas aí não existem apenas cubatas; entre elas também se elevam prédios de pedra e tijolo, cobertos de telha ou de chapa ondulada, propriedades de gente que os pode mandar construir e que, na maior parte dos casos, servem para arrendamento de habitações e lojas. Não há rede de esgotos, nem de fornecimento de electricidade e água ao domicílio.
A Chicala II ainda está separada do sector da Ilha de Luanda com o mesmo nome por um canal marginado por areias e vasa, cuja largura, constantemente alterada, oscila entre $20-25$ e $50 \mathrm{~m}$ (fig. 15). A sua existência pouco altera as condições criadas para a segmentação da Baía da Samba, ficando a parte mais setentrional, entre aquele apêndice e a ponte da Ilha (cerca de 700 $\mathrm{m}$ de distância) transformada numa laguna (700 por $400 \mathrm{~m}$ ) receptora de sedimentos naturais, de lixos
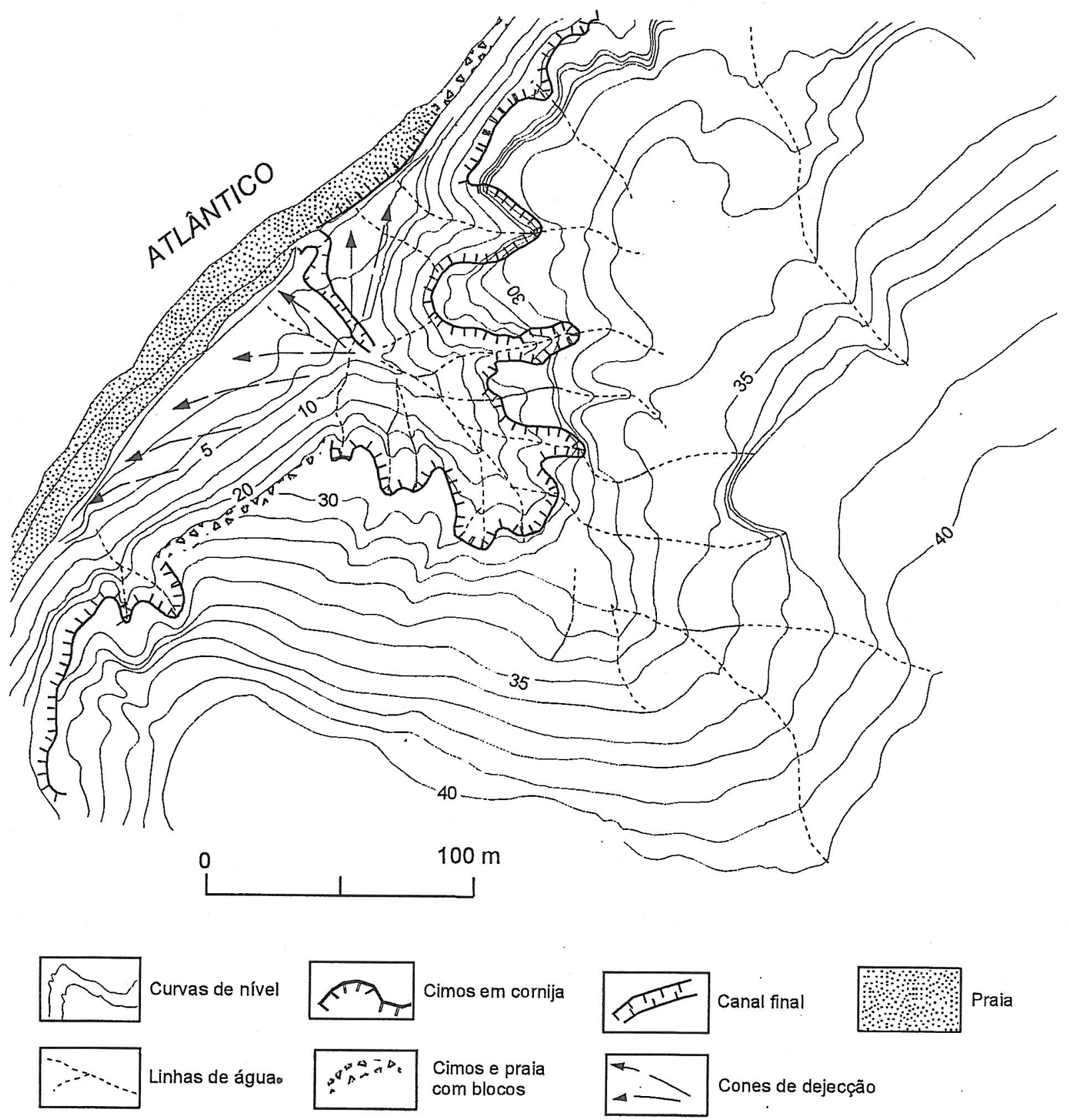

Fig. 17 - Esboceto geomorfológico de uma barroca digitada na área de Belas, a sul de Luanda. 
domésticos e outros, de urinas e excrementos humanos, etc., um verdadeiro foco de riscos para a saúde pública.

Um dos aspectos mais interessantes do arco da Praia do Bispo-Samba está, sem dúvida, no comportamento dos processos de erosão, nomeadamente nos de abertura de ravinas ou barrocas, e na evolução das formas de relevo locais, isto é, de vertentes, de plainos e outras congéneres, depois das obras de terraplenagem de larga escala efectuadas em anos recentes logo a sul da Alameda arqueada que mencionei em linhas anteriores. Onde havia barrocas, o arrasamento e recuo de escarpas abarrocadas e o enchimento de depressões ou covas criaram um vasto plano inclinado e alisado em forma de leque aberto desde o cruzamento das ruas Comandante Dak-Doi e dos Heróis (cerca de $30 \mathrm{~m}$ de altitude) até à orla convexa de praia da baía (cerca de $2 \mathrm{~m}$ de altitude), sendo de um pouco mais de $950 \mathrm{~m}$ a distância do primeiro à segunda, medida numa linha média que passa pelo Mausoléu (fig. 16).

Ora bem, tais obras foram feitas como parte de um projecto grandioso que tinha como núcleos principais o Mausoléu do Dr. António Agostinho Neto, primeiro Presidente da República Popular de Angola, uma construção de grande altura no centro uma praça monumental. Substituído o regime marxista-leninista pelo capitalista, as obras foram suspensas e os terrenos, ainda mal consolidados, ficaram abandonados às intempéries naturais - chuvas intensas de Março e Abril, humidade atmosférica sempre elevada, variações térmicas, etc. - às quais se têm de juntar as intervenções humanas, nem sempre correctas em relação às condições criadas por elas próprias em tempos recentes.

Oplano inclinado, se não for devidamente escorado, facilitará a escorrência laminar e, sobretudo, a turbilhonar das águas pluviais. A primeira terá efeitos de "varredura" e arrastamento dos materiais finos mais superficiais e a segunda os de abertura de regueiras, muitas das quais poderão tornar-se em sulcos originais de ravinas ou barrocas. A inclinação para o mar dará a esses processos melhores condições de actuação, incluindo os de anastomose de regueiras ou de sulcos mais profundos.

Quantoàs barrocas ou ravinas que foram decepadas, por corte ou por enchimento das suas partes jusantes, ficando as superiores, no caso de não haver obras sustatórias, os novos pontos de inflexão, colocados em posições mais elevadas, passarão a funcionar como níveis de base temporários de regularização, dominada pelos processos de erosão regressiva, que podem revelar-se mais agressivos do que anteriormente. Se assim for, tal como no caso anterior, estão exacerbadas, potencialmente, as condições de riscos naturais.

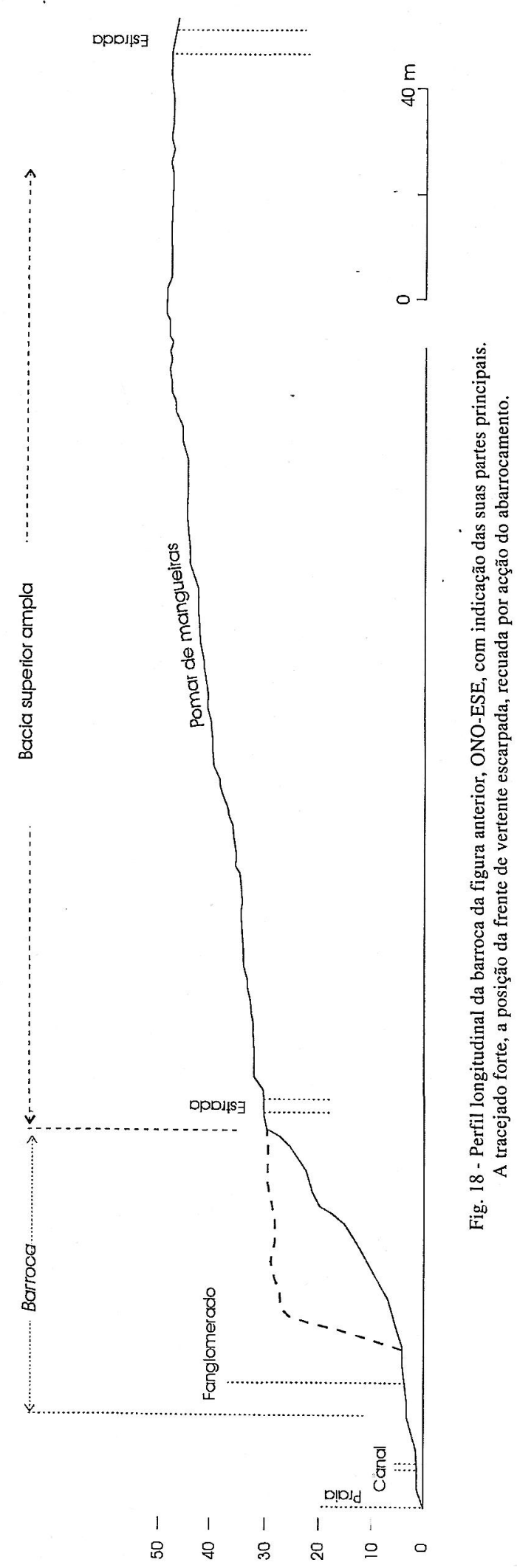


territorium 9.2002

\section{Barrocas fora da área urbanizada}

\section{Barrocas de Belas, viradas a $O$}

Defronte da Barra da Corimba as vertentes escarpadas e abarrocadas não orlam baías resguardadas porcordões de areias, como sucede nos arcos anteriores, mas estão demasiado perto das águas oceânicas com a sua forte ondulação. Quando muito, intercalam-se estreitas faixas de praias que as calemas invadem com facilidade. Assim, temporariamente, as escarpas, de $40 \mathrm{~m}$ de altura e mais, podem voltar a ser arribas.

Confesso que não tive muito tempo para me debruçar, no terreno, sobre estas escarpas-arribas

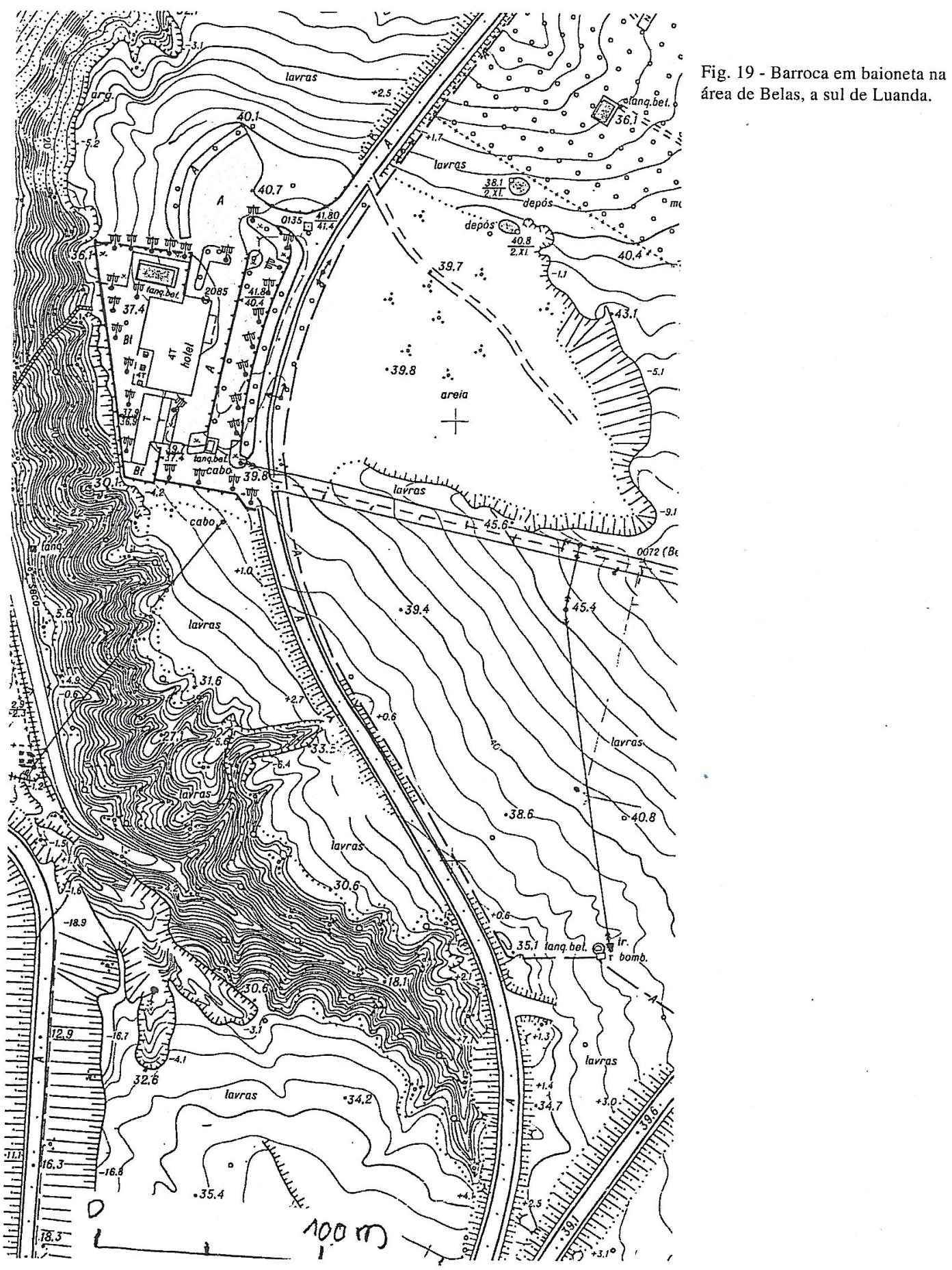


com as suas barrocas. Não obstante, tendo em consideração as suas características gerais, diferentes das anteriores, achei por bem juntar alguns apontamentos, ainda que incompletos, sobre duas barrocas complexas, muito próximas uma da outra, ambas abertas para noroeste (figs. 17 a 19).

De uma forma geral, sob as areais vermelhas e lentes de burgaus do planalto afloram leitos de argila, bancadas de areias, umas claras outras rubificadas, de arenitos calcários e calcários, e de margas. Sob a acção dos processos erosivos as rochas mais resistentes dão saliências nas vertentes e frentes de barrocas ou ravinas, sob a forma de pequenos abruptos ou degraus; as mais brandas, pelo contrário, estão recuadas, em sectores reentrantes.

$\mathrm{Na}$ barroca mais setentrional, de plano digitado, a bacia de alimentação, de declive relativamente suave, foi cortada pela estrada de Luanda para o Cuanza (fig. 17). Como sucede com a generalidade das barrocas, essa bacia é demasiado ampla, com área muitíssimas vezes superior à da barroca propriamente dita. Noutros lados pude obter valores da ordem de 40 ha para a primeira e de 15 para a segunda; no caso que aqui interessa, basta ver as figuras 17 e 18 para se ter uma ideia da enorme desproporção. A partir da estrada, colocada a $30 \mathrm{~m}$ de altitude, está a barroca com o seu perfil longitudinal tenso, de forte declive, com uma queda de 30 para 5 $\mathrm{m}$, iniciada por um rebordo estreito e vertical bem demarcado no terreno. $O$ sector mais tenso do perfil longitudinal termina num amplo leque de cones de dejecção com cerca de $200 \mathrm{~m}$ de frente, no contacto com a estreita faixa de praia arenosa.

Nalguns percursos pude observar vários testemunhos dos regimes de escoamento das águas. No planalto, de declives muito suaves onde, por isso mesmo, a velocidade de escoamento será pequena, inferior à de erosão, as superfícies topográficas apresentavam-se quase lisas ou ligeiramente onduladas, de quando em quando com alguns sulcos dotados de capacidade de retracção. Eram mais vulgares as fendas de dissecação, abertas nos meses mais secos e de fortes amṕlitudes térmicas. Nas proximidades das cabeceiras das barrocas saltavam à vista as mudanças topográficas marcadas pelo entalhe de ravinas ou sulcos mais profundos, prenunciativos da queda e drenagem turbilhonar das águas no sector mais tenso do perfil longitudinal, entalhado na escarpa ou arriba, com maior velocidade e capacidade de arrastamento de clastos de todas as dimensões, fornecidos, abundantemente, pelas bancadas sedimentares, já soltos ou arrancados delas. A parte final das barrocas, como já foi referido, corresponde a um pequeno sector de deposição de cargas arrastadas pelas águas turbilho-

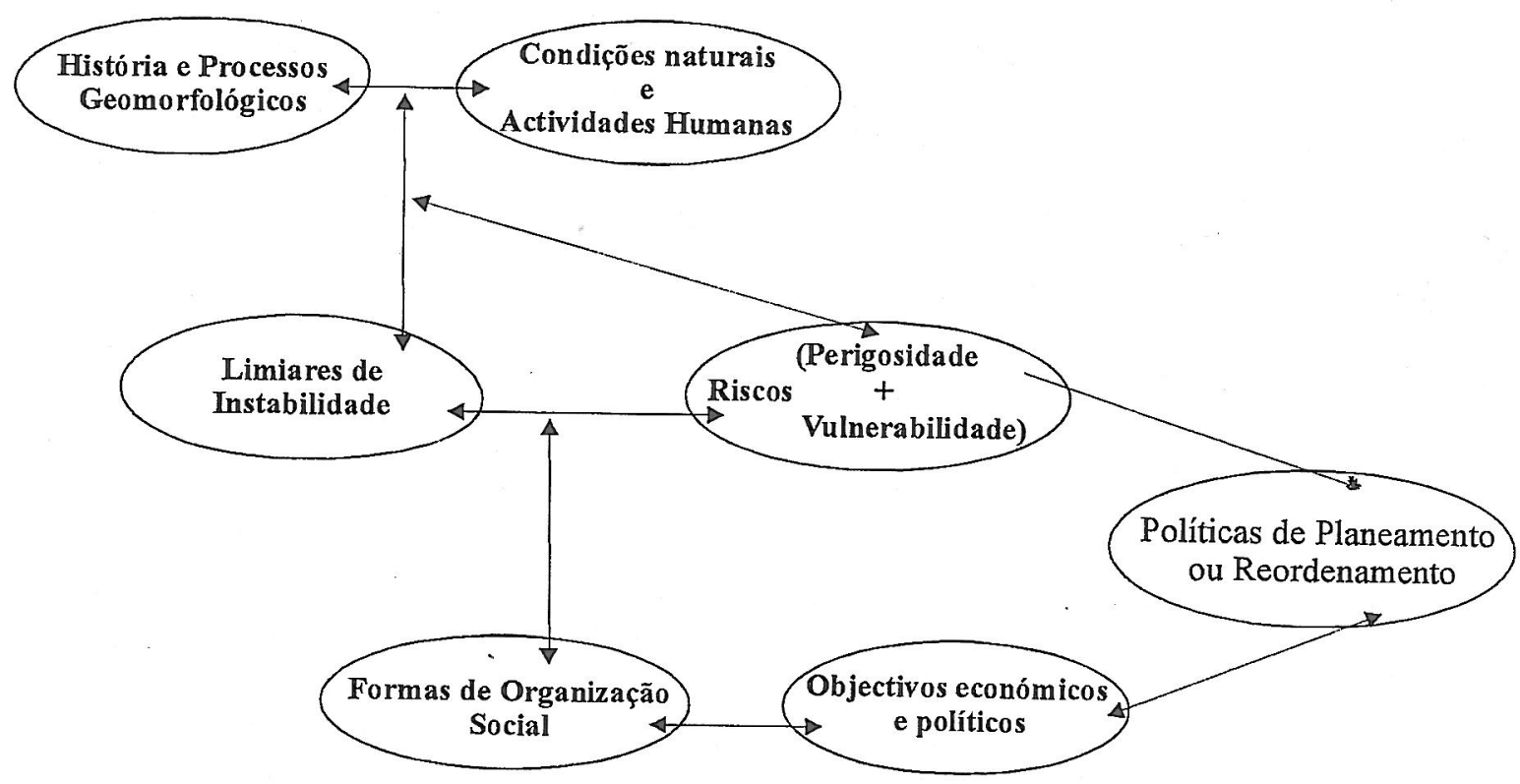

Fig. 20 - Proposta de um modelo teórico com domínios que poderão intervir nos estudos de escarpas, barrocas e praias, e das suas interligações, para a definição de políticas adequadas de planeamento ou reordenamento territorial. 
nares, dos clastos fornecidos pelas vertentes das ravinas por desmoronamento e deslizamento. Nos escombros também contam os materiais caídos ou deslizados das frentes das escarpas. Impõe-se aqui o estudo dessas contribuições, a par de outros factores, numa tentativa de avaliação das relações complexas entre a evolução das ravinas e o recuo das escarpas.

Estes processos, na sua globalidade, terão "como consequência uma progressão anual das cristas das barrocas para montante, progressão essa que só terminará quando se anular o desnível torrencial entre a crista e a base das barrocas, dando lugar" a uma vertente de inclinação mais suave (Ú. Nascimento, 1952, pp. 23-24). Sendo esta a tendência teoricamente previsível, todavia o resultado, por motivos diversos, dos quais recordarei apenas dois, poderá não ser esse: o recuo das escarpas, paralelamente às suas posições originais, e a importância e reflexos das variações altimétricas do nível de base.

A outra barroca referida anteriormente, localizada logo a sul, apresenta características análogas e algumas diferenças importantes: um comprimento maior, um plano que não é digitado; um curso com duas mudanças de rumo - no sector inicial a um troço sul-norte, de pouco mais de uma centena de metros, acompanhado, paralelamente, pela estrada de Luanda para o Cuanza, que também corta a sua bacia de alimentação, sucede um desvio para oeste, de cerca de $200 \mathrm{~m}$, seguindose de novo, até à praia, o rumo S-N do troço de maior comprimento; e um encaixe maior. Estará a barroca adaptada a fracturas ou falhas cruzadas? Fica isto como hipótese de trabalho.

Nas duas barrocas pude observar outros aspectos interessantes, merecedores de referências, ainda que muito breves. Por causa do entulho do sector terminal e consequente elevação do ponto de inflexão, as ravinas, ainda muito activas, tendem a recuperar as situações anteriores noprocesso evolutivo de construção dos seus perfis de equilíbrio escavando nos cones de detritos um canal de paredes abruptas. No caso da primeira ravina ele está orientado, como ela, para noroeste e, por factores de resistência locais e por vezes temporários, encurva primeiro para norte e depois para sul ao entrar na praia.

Como em muitas ravinas afluentes de uma principal, entroncando nela a alturas diferentes, foi possível observar dispositivos idênticos, isso leva-me a crer em processos de ravinação descontínua, um fenómeno semi-ciclico em que os cones de dejecção acabam por adquirir gradientes demasiado acentuados em relação à média geral, oferecendo assim condições e espaços para a abertura de novas ravinas. Mas o resultado final será o da coalescência dos diferentes canais num só. Para esses processos e formas utilizo a expressão de gully-in-gully, à maneira da tão vulgarizada de valley-in-valley.

\section{Algumas palavras finais}

Procurei pôr em relevo as características geográficas de dois arranjos topográficos complexos aos quais estão ligadas, intima e permanentemente, a génese e a evolução da cidade de Luanda: por um lado, a grinalda de restingas e ilhas arenosas baixas que protegem a baía (ou baías, se consideradas a de Luanda e a da Samba) das vigorosas variações e ondulações oceânicas, e, por outro lado, os arcos de escarpas altas dos limites interiores dessa baía (ou baías) e da Cidade Baixa, modeladas em bancadas sedimentares e densamente abarrocadas. Diferentes, quer na geologia, quer na geomorfologia, contudo, têm de comum factores idênticos de vulnerabilidade e de perigosidade, que acções antrópicas desadequadas têm exacerbado.

A defesa e conservação da Ilha de Luanda, longa e estreita, perante os ataques intensos das águas oceânicas e arrastamento das areias, sobretudo em épocas de calemas, podendo resultar disso a sua fragmentação, a fixação das barrocas para minorar os efeitos desastrosos das águas torrenciais nas ravinas, de fortes chuvadas concentradas em período curto do ano, e tentar travar o recrudescimento da erosão regressiva das suas cabeceiras constituem dos problemas mais graves da conservação da cidade, exigindo o conhecimento científico das situações de crise, a utilização de técnicas apuradas e a disponibilidade de capitais avultados.

Muitos erros têm sido cometidos mas, à questão de Quid agendum? (e agora que fazer?) é de esperar que possa ser posto em prática o princípio de Errando corrigitur error! (Errando se corrige o erro!). Alguns leitores, ao chegarem ao fim deste texto, poderão ter desejado que ele fosse menos descritivo e mais recheado de pormenores com base em análises geológicas e geomorfológicas minuciosas, em medições de fenómenos erosivos no terreno, em informações sobre formas de vigilância existentes ou a aconselhar, etc., etc. Tudo isso está reservado para um trabalho de maior profundidade cuja continuação aguarda a oportunidade de poder voltar ao terreno, em estada relativamente longa, para reexaminar, in situ, os processos e as formas, explorar outros locais, colher amostras e novos dados, ter acesso a trabalhos que tenham sido feitos em tempos mais recentes.

Por ora termino com um modelo teórico que tem em conta vários domínios do conhecimento e de acção, as suas interligações e variações no espaço e no tempo. Não sendo possível desenvolver o que está apenas indicado na figura 20 , advirto que não se trata de um modelo hermético, e único, mas sim de proposta ou propostas orientadoras de inquéritos e estudos para a melhor compreensão dos factores de vulnerabilidade dos dois sistemas topográficos e dos riscos 
que pendem sobre a cidade, de modo a definirem-se políticas realistas e exequíveis de planeamento ou de reordenamento, tendo em conta que o Plano tem de ser evolutivo e nunca involutivo.

\section{Bibliografia indicada no texto}

AMARAL, Ilídio do (1968), Luanda. Estudo de geografía urbana. Lisboa, Junta de Investigações do Ultramar.

AMARAL, Ilídio do (1985), "Processsos e formas de evolução do relevo em rochas da Orla Sedimentar do deserto de Moçâmedes (Angola)-1 ${ }^{a}$. Parte", Garcia de Orta. Série de Geografia, Lisboa, 10(1-2), pp. 1-40.

AMARAL, Ilídio do (2000a), O consuladode Paulo Dias de Novais. Angola no último quartel do século XVI e primeiro do século XVII. Lisboa, Instituto de Investigação Científica Tropical.

AMARAL, Ilídio do (2000b), "Geografia física das regiões tropicais: reflexões geomorfológicas (I)", Garcia de Orta. Série de Geografia, Lisboa, 17(1-2), pp. 1-22.

CARVALHO, Gaspar Soares de (1964), "As areias superficiais de Luanda (Angola) e dos seus arredores", Garcia de Orta, Lisboa, 12(4), pp. 695-706.
GUILCHER, André, MEDEIROS, Carlos Alberto, MATOS, José Esteves de, OLIVEIRA, José Tomás (1974), "Les restingas (flèches littorales) d'Angola, spéciallemnt celles du Sud et du Centre", Finisterra. Revista Portuguesa de Geografia, Lisboa, IX, pp. 171-210.

LOPES, Duarte e PIGAFETTA, Fillipo (1591, em italiano), Relação do Reino de Congo e das Terras circunvizinhas. Lisboa, Agência Geral do Ultramar, 1951, tradução de Rosa Capeans; também Benavente, Câmara Municipal, 2000 (reedição), com Estudo Introdutório de I. do Amaral.

NASCIMENTO, Úlpio (1952), Estudo da regularização e protecção das barrocas de Luanda. Lisboa, Laboratório Nacional de Engenharia Civil, Relatório 30.

REBELO, Fernando (2001), Riscos naturais e Acção antrópica. Coimbra, Imprensa da Universidade.

Agradeço aos meus colaboradores do Centro de Geografia do IICT, a Assessora Dra Ana Amaral, pela cuidada execução, por meios informáticos, de quase toda a ilustração gráfica, exceptuadas as reproduções fotográficas e a fig. 19; e o Investigador. Auxiliar Mestre Fernando Lagos Costa, pela elaboração dos primeiros esboços das figs. 10 e 17.

Lisboa, Setembro de 2002. 
